\title{
Heat and Mass Transfer in Open Evaporative Cooling System Using Various Types of Fills In Oil Industry
}

\author{
Dr.Nagam Obaid Kariem \\ College Of Engineering Al- Mustansiry University
}

\section{$\underline{\text { Abstract }}$}

This research work is to study the performance of evaporative cooling system using new type of packing with different shapes (saddle, counter current wavy, and triangular splash) and materials (glass, thermoplastic, and resistance wood) of packing for an air -water cooling system. The basis of the installation is the evaporative cooling system, $1.75 \mathrm{~m}$ height and 40 x $40 \mathrm{~cm}$ outside cross section. The fluids in this system are air which moving from the bottom to the top of cooling system (mass flow rates ranging between 0.07 and $0.18 \mathrm{~kg} / \mathrm{s}$ ) and the water which are moving from top to bottom of cooling evaporator ((mass flow rates ranging between 0.11 and $0.27 \mathrm{~kg} / \mathrm{s})$ ). The inlet water temperatures ranging between 35 and $55^{\circ} \mathrm{C}$. The packing heights were changed during the research in order to get the temperature profile and the relation of these temperatures with the other variables in the cooling system, the packing heights ranging between 35 to $140 \mathrm{~cm}$. The overall volumetric heat and mass transfer coefficients and tower characteristics, were predicted as a function of the fluids flow rates.

A computer program used to solve and find the relation between the variables in the system and the functions (overall volumetric heat and mass transfer coefficients, number of transfer coefficient, the temperature variation along the tower). 
The results show that :

1-At maximum air mass flow and minimum water mass flow, the mass transfer coefficients would be on the maximum value and vice-versa.

2- The thermoplastic packing was much more efficient than glass and wood by efficiency about 12 to $18 \%$. ,also the results showed that The triangular packing was much more efficient than wavy and glass by efficiency about 5 to

$11 \%$.

3-The temperatures distribution were not constant in all layers; the temperatures distribution in the first layer were not very well, this happened because the distribution of water in the packing surface was just know happened, while in the other layers the temperature distribution and profile were so good.

Key words: cooling, saddle, wavy, triangular, glass, thermoplastic, wood, temperature distribution

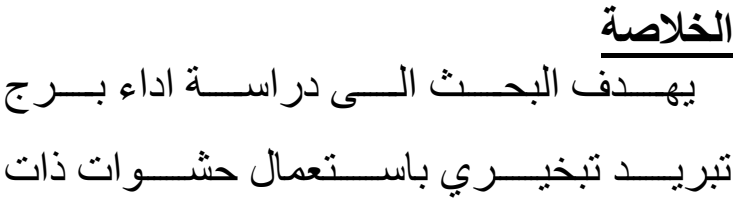
saddle, counter ) اثــكال مختلفــة current wavy, and triangular glass ) و مهـواد مختلفــة (splash thermoplastic, and resistance

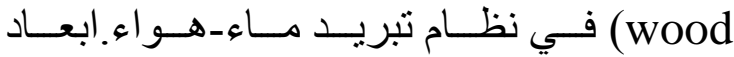

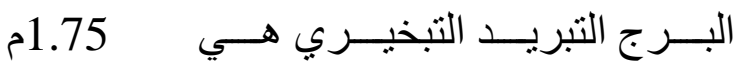

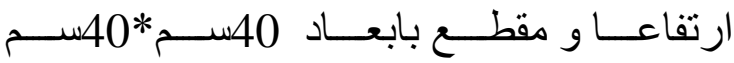

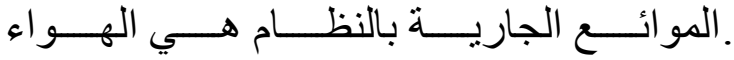
ويـــل مــن اســل النظــام و يخــرج مــن الاعلــى وبمعــلات جريــان كتلــي يتـــراوح بين 0.07 الى 0.18 كغم|ثاراما المائع

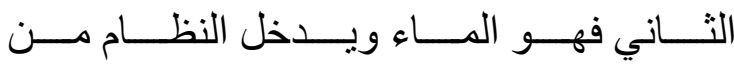
الاعلــى و يخــرج مــن الاســفل و بمعـدلات جريــان كتلـي تتــراوح بـين 0.110

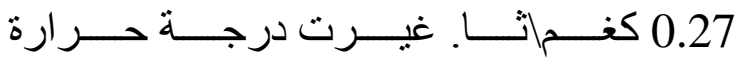

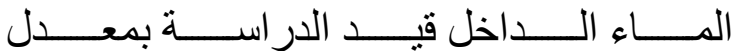

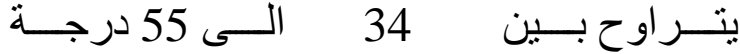

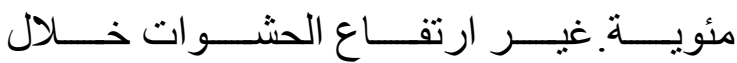

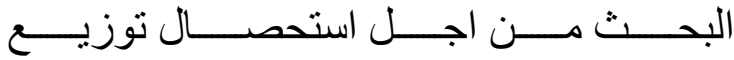

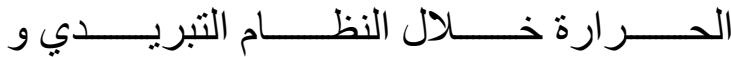

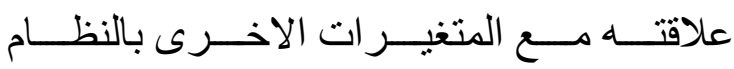

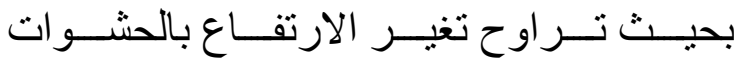

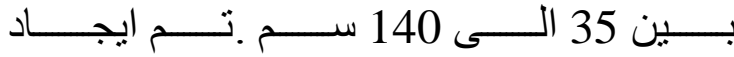
معـــــــاملات الاداء و انتق لـــــــال المـــــــادة و الحـــــرارة و العلامــــة بيــــنهم و معــــلات

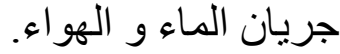




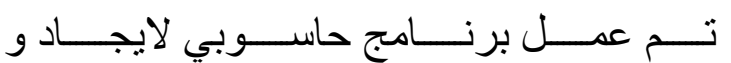

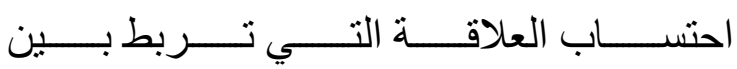

متغيـــــر ات النظــــــام و الـــــدو ال المختلفــــــة

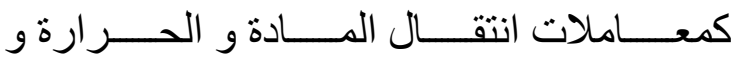
و و Tie-line درجات الحرارة خلال نظام التبريد. بينــت النتــائج انــهه عنــد اعلــى معـدل جريــان للهـــو اءو واقـلـل معـــل جريــان للمـــاء يكــون

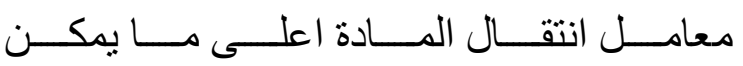

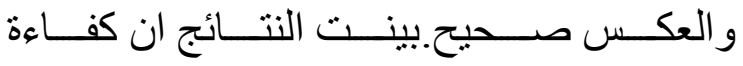
الحشــــوة نـــوع اكثـــ اكر

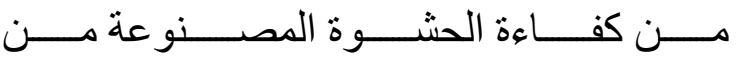

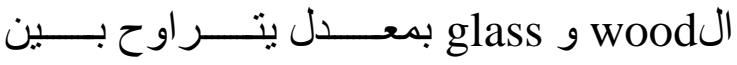

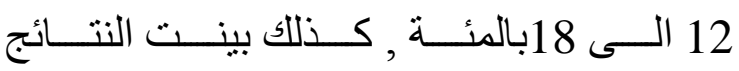

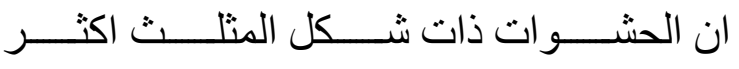

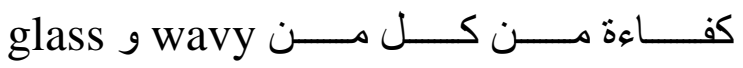

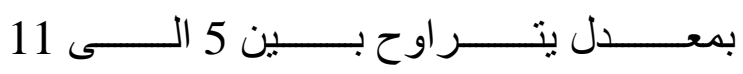

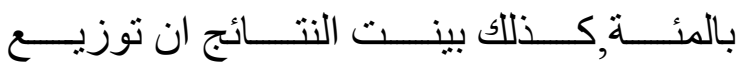

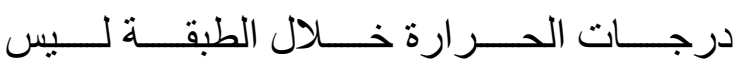

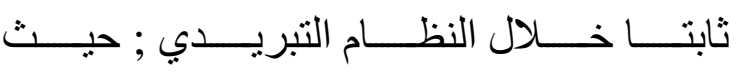
توزيـــع درجــات الحــرارة خــلال الطبقـــات

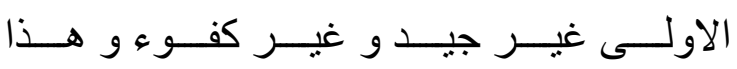

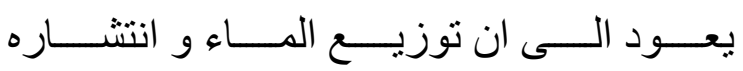

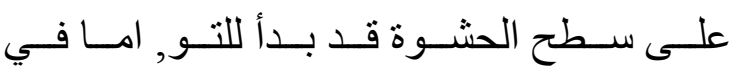
بــــاقي الطبقــــات فـــان توزيـــــع درجــــــات الحرارة يكون جيد جدا.

\section{Introduction:}

Cooling towers of interest play an important role in the cool-end system of power plant, and its cooling capacity can affect the total power generation capacity directly(1-4). In reality, there are various types of cooling towers, and among of them, natural draft counter-flow wet cooling towers are utilized widely in large-scale power plants, the cooling efficient is highly sensitive to environmental conditions, particularly for most cases under the cross-wind conditions that may reduce dry-cooling towers up to $40 \%$ of the total power generation capacity. However, the best knowledge, for the conventional design of cooling towers, the impact of cross-wind, which actually exists in most cases, has not been paid more attention. Therefore, it is really crucial to delve the influence of cross -wind regarding the heat transfer performance of cooling towers.

A theoretical analysis of closed wet cooling was presented for the heat and mass transfer 
coefficients using the Lewis relation[5] . Applied CFD code to predict the performance of a closed cooling tower by using a two-phase flow of air and water droplets on the outside tube[6]. [7,8] developed a mathematical model for predicting the performance of cooling towers and their results were validated by measured data. Facao and Oliveira [9] compared simplified models with detailed models and noticed that simplified models based on an overall approach provide as good or even better results as those based on finite differences .A simplified model for closed wet cooling towers based on effectiveness models using a simplification of heat and mass balance equations[10] .

The performance of heat exchanger was analyzed for the closed wet cooling tower [11]. The experiments have been conducted using two heat exchangers that had different tube diameters and arrays. The heat transfer co-efficient could be calculated from the equation for external tube surfaces of tube banks.
The mass transfer coefficient calculated from the heat and mass transfer analogy was compared with experimental data. The regulated correlation equations were obtained from the result of the comparison. The cooling capacity and thermal efficiency of the closed wet cooling tower were calculated from provided equation and the performance of the tower were investigated.

Fouling models was analyzed and described its impact on the thermal performance of the cooling towers[12] . A cooling tower model in conjunction with the fouling model is used to study the effect of fouling on tower effectiveness and water outlet temperatures for a small size cooling tower operating under similar conditions.

The thermal performance of a forced draft counter-flow wet cooling tower fitted with different drift eliminators was studied for a wide range of air and water mass flow rates[13]. The data registered in the experimental set-up were employed to obtain correlations of the tower 
characteristic, which defines the cooling tower's thermal performance. The outlet water temperature predicted by these correlations was compared with the experimentally registered values obtaining a maximum difference of $\pm 3 \%$.

The performance predictions of a simple one-dimensional natural draft wet cooling tower model and a twodimensional axisymmetric numerical model are compared under a range of design parameters. The twodimensional model has the ability to resolve radial non-uniformities across the tower which the onedimensional model only computes as a bulk averaged value. The difference between the overall cooling range predicted by the two models is generally less than $2 \%$, with no divergence in the agreement between the methods with respect to any design parameter[14] .

The performance for counter-flow wet cooling tower is predicted by using heat and mass transfer between water and air to drive the solution to steady-state conditions. The second law is used to take account of energy distributions of water and air in cooling tower[15]. Investigation of the calculated results can be used to further understand details of energy in cooling towers.

The aim of this work is to study the performance of evaporative cooling system using new type of packing with different shapes (saddle, counter current wavy, and triangular splash) and materials (glass, thermoplastic, and resistance wood) of packing for an air -watercooling tower .

\section{Apparatus and experimental}

\section{Procedure:}

An evaporative cooling system was designed and the layout of experimental apparatus was shown in figure(1). The general arrangement was made in a certain way to provide maximum accessibility to the tower section for observation and maintenance without restricting the operation. 
The arranging of equipments and measuring devices placed in away so that the overall material and energy balances could be achieved. The Water circulation during a run was maintained in a closed system. The water from the tower basin was pumped by means of a centrifugal pump. The water passes to the stainless steel water-heating tank, then to the water distribution system over the packing.

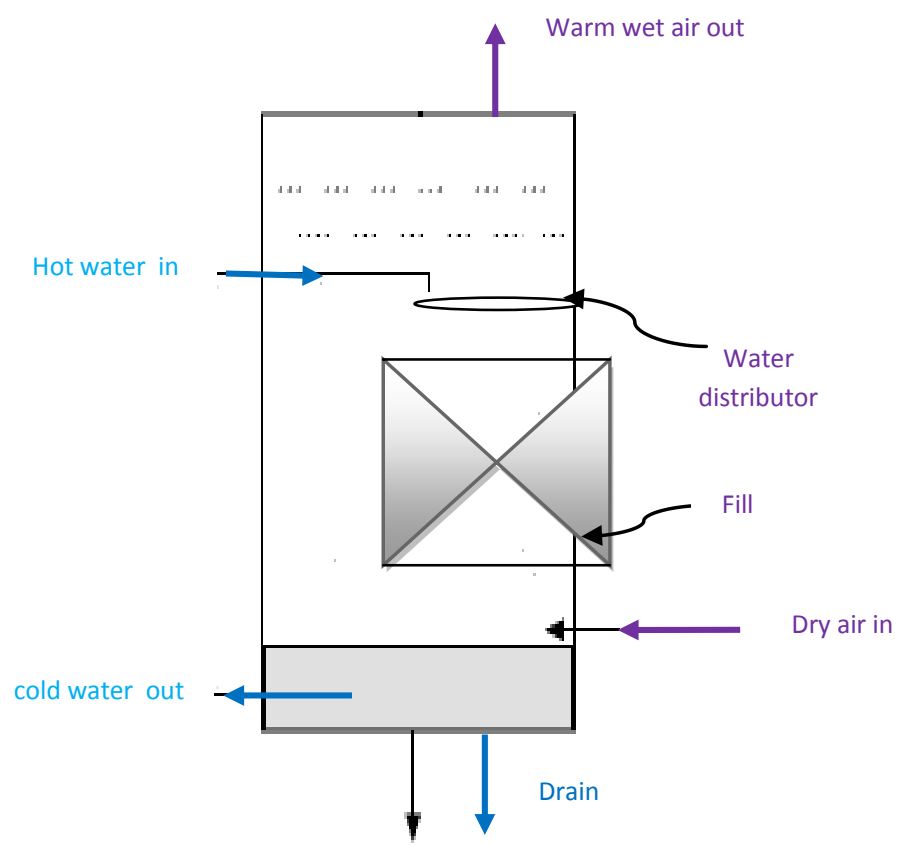

Fig. (1) Block diagram of evaporative cooling system

Water was spreading on the top of packing edge by means of spike-8-inch fixed distributer shower as shown in figure (2). The distribution system insured film flow of water on the packing. The water flow rates were measured by rotameter . 


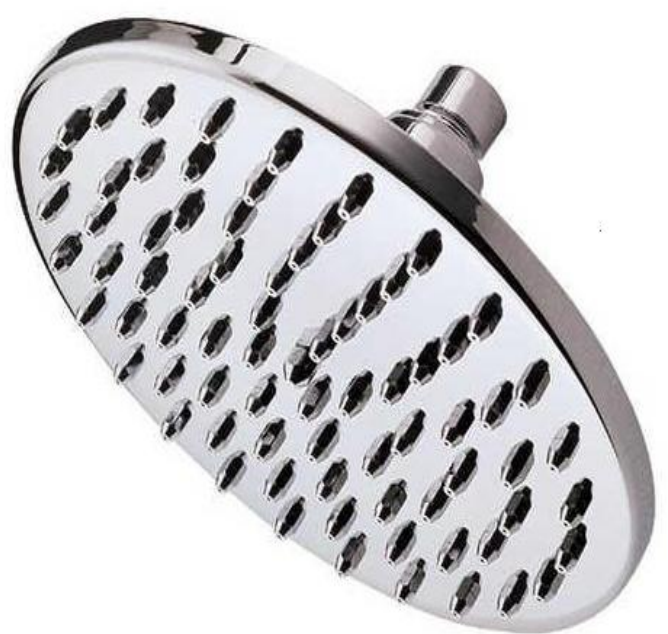

Fig. (2) Spike-8-inch fixed distributer shower

The evaporative cooling system is $400 \mathrm{~mm}$, by $400 \mathrm{~mm}$, in cross section and the height between inlet water distributor and inlet air distributor in the tower is $1.5 \mathrm{~m}$.

Thick Perspex was bolted to the front direction of the tower. This was used to provide more flexibility of opening the tower and the fluids (water and air) movement inside the system.

The air moving into the test section from the bottom body evaporative cooling system . This arrangement of movement provides a counter current between water and air. A mist eliminator made out of PVC pad $(400 \mathrm{~mm} \times 400 \mathrm{~mm})$ was placed on the top of the water distributor.
A centrifugal fan supplying air through the cooling system was connected with a dumper .Air volume flow rates were measured by means of an independently calibrated inclined U-manometer.

The vehicle of mass and heat transfer in the evaporative cooling system was the packing. The packing was made from different packing materials (glass, thermoplastic, and resistance wood), and $0.35,0.7$, 1.05 , and $1.4 \mathrm{~m}$ height . This changed height was in order to study the end effects. Figure (3) shows the three shapes of packing that used in this research. In order to smooth distribution the distance between the water distribution tubes and the top of packing is $5 \mathrm{~cm}$. 


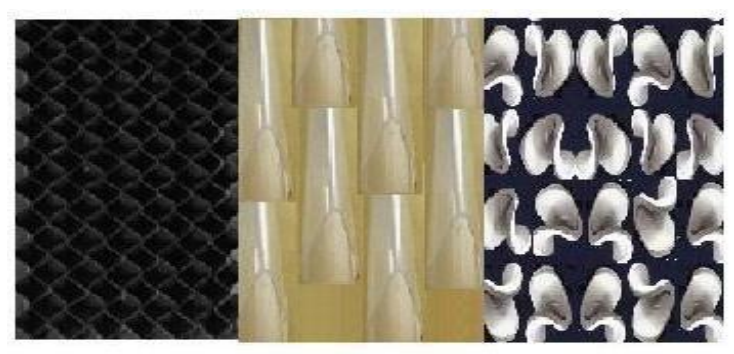

Fig. (3) The three shapes of packing (wavy, triangular, and saddle respectively).

An eleven thermocouple were used to measure the temperature of air and water, located in a manner such that the weighted average temperature of air or water were determined at each point, except the inlet water temperature that achieved by a single thermocouple .The thermocouples are calibrated with calibrated mercury in glass thermometers .

In order to study the water temperature profile along the evaporative cooling at different air and water conditions, forty eights thermocouples were used.

The thermocouples are labeled according to the layer such as thermocouple number $\mathrm{A}_{1}, \mathrm{~A}_{2}, \ldots$, $\mathrm{B}_{1}, \mathrm{~B}_{2}, \mathrm{~B}_{3}, \mathrm{C}_{1}, \mathrm{C}_{2}, \mathrm{C}_{3} \ldots$. etc were adopted . Precautions were taken to ensure the strength of these connections.
Sixteen thermocouples are placed in the first layer which is $0.35 \mathrm{~m}$, away from the top of the packing. These thermocouples are labeled from $\mathrm{A}_{1}$ to $\mathrm{A}_{16}$ which are arranged in the form of $4 \times 4$ matrix, Fig. (4.a) .

The second set of thermocouples are placed $0.7 \mathrm{~m}$ away from the top of the packing which are labeled from $B_{1}$ to $B_{16}$, which are arranged in the form of $4 \times 4$ matrix, Fig. (4.b) .

The third set of thermocouples are placed $1.05 \mathrm{~m}$, away from the top of the packing which are labeled $\mathrm{C}_{1}$ to $\mathrm{C}_{16}$.The thermocouples are arranged in the form of $4 \times 4$ matrix, Fig. (4.c) . The final set of thermocouples are placed $1.4 \mathrm{~m}$, away from the top of the packing which are labeled $\mathrm{D}_{1}$ to $\mathrm{D}_{16} \quad$.The thermocouples are arranged in the form of $4 \times 4$ matrix, Fig. (4.d) . 


\begin{tabular}{|l|l|l|l|l|l|l|l|l|l|l|l|l|l|l|l|}
\hline $\mathrm{A}_{1}$ & $\mathrm{~A}_{2}$ & $\mathrm{~A}_{3}$ & $\mathrm{~A}_{4}$ & $\mathrm{~B}_{1}$ & $\mathrm{~B}_{2}$ & $\mathrm{~B}_{3}$ & $\mathrm{~B}_{4}$ & $\mathrm{C}_{1}$ & $\mathrm{C}_{2}$ & $\mathrm{C}_{3}$ & $\mathrm{C}_{4}$ & $\mathrm{D}_{1}$ & $\mathrm{D}_{2}$ & $\mathrm{D}_{3}$ & $\mathrm{D}_{4}$ \\
\hline $\mathrm{A}_{5}$ & $\mathrm{~A}_{6}$ & $\mathrm{~A}_{7}$ & $\mathrm{~A}_{8}$ & $\mathrm{~B}_{5}$ & $\mathrm{~B}_{6}$ & $\mathrm{~B}_{7}$ & $\mathrm{~B}_{8}$ & $\mathrm{C}_{5}$ & $\mathrm{C}_{6}$ & $\mathrm{C}_{7}$ & $\mathrm{C}_{8}$ & $\mathrm{D}_{5}$ & $\mathrm{D}_{6}$ & $\mathrm{D}_{7}$ & $\mathrm{D}_{8}$ \\
\hline $\mathrm{A}_{9}$ & $\mathrm{~A}_{10}$ & $\mathrm{~A}_{11}$ & $\mathrm{~A}_{12}$ & $\mathrm{~B}_{9}$ & $\mathrm{~B}_{10}$ & $\mathrm{~B}_{11}$ & $\mathrm{~B}_{12}$ & $\mathrm{C}_{9}$ & $\mathrm{C}_{10}$ & $\mathrm{C}_{11}$ & $\mathrm{C}_{12}$ & $\mathrm{D}_{9}$ & $\mathrm{D}_{10}$ & $\mathrm{D}_{11}$ & $\mathrm{D}_{12}$ \\
\hline $\mathrm{A}_{13}$ & $\mathrm{~A}_{14}$ & $\mathrm{~A}_{15}$ & $\mathrm{~A}_{16}$ & $\mathrm{~B}_{13}$ & $\mathrm{~B}_{14}$ & $\mathrm{~B}_{15}$ & $\mathrm{~B}_{16}$ & $\mathrm{C}_{13}$ & $\mathrm{C}_{14}$ & $\mathrm{C}_{15}$ & $\mathrm{C}_{16}$ & $\mathrm{D}_{13}$ & $\mathrm{D}_{14}$ & $\mathrm{D}_{15}$ & $\mathrm{D}_{16}$ \\
\hline
\end{tabular}

Fig.(4.a) Layer one

Fig.(4.b) Layer two

Fig.(4.c) Layer three

Fig.(4.d) Layer

four

Fig.(4) Thermocouples arrangement in four different high through cooling evaporator.

\section{Computational model:}

Ten assumptions that are used to derive the computational model equations may be summarized as follows;

1. Steady heat and mass transfer.

2. Constant cross sectional area of the tower.

3. Constant evaporative cooling system.

4.Negligible heat and mass transfer through evaporator walls to the environment.

5. Constant water and dry air specific heats.

6. Constant heat and mass transfer coefficients throughout the cooling system.

7. Lewis number is constant throughout the evaporative cooling system.

8. Drift eliminator is not effective on the water loss.

9.Heat and mass transfer is in a direction normal to the flows only. 10. There is average temperature throughout the water at each level.

The number of transfer units of the cooling system are calculated by a program, which is depending on the equations from eq.(1) to eq.(8) (the program calculate the number of transfer units and other functions of the open evaporative cooling system as shown in figure(5),this program was made by visual basic version five). 
Equation of mass balance on an increment volume(see fig.(6));

$\dot{f}_{a} d h=\dot{f}_{w} d h_{f . w}+f_{a} d \dot{w}_{h f, w}$

Equation of energy balance for water(see fig.(6));

$\dot{f}_{w} d h_{f, w}=h_{c} A_{v} d V\left(T_{w}-t\right)+h_{D} A_{v} d V\left(W_{s, w}-W\right) h_{f g, w}$

Equation(2) with Lewis number becomes ;

$\dot{f}_{w} d h_{f, w}=h_{D} A_{v} d V\left[\right.$ Le CP $\left.a\left(T_{w}-t\right)+\left(W_{s, w}-W\right) h_{f g, w}\right]$

Equation of mass balance for air side water vapor;

$\dot{f}_{a} d W=h_{D} A_{v} d V\left(W_{s, w}-W\right)$

Since

$\frac{h_{D} A_{v} V}{\dot{f}_{w}}=c\left(\frac{\dot{f}_{w}}{\dot{f}_{a}}\right)^{n}$

From ASHRAE[16]

And equation of number of transfer unit is as follows

$$
N T U=\frac{h_{D} A_{V} V}{\dot{f}_{a}}=\int_{W_{i}}^{W_{o}} \frac{d W}{W_{s, w}-W}
$$

By adding equation(5) to equation(6) we get the following;

$$
N T U=c\left(\frac{\dot{f_{w}}}{\dot{f_{a}}}\right)^{n+1}
$$

The tie-line slope calculated by the following equation;

$$
\text { Tie }- \text { line slope }=\frac{-h_{c, w}}{h_{D}}
$$




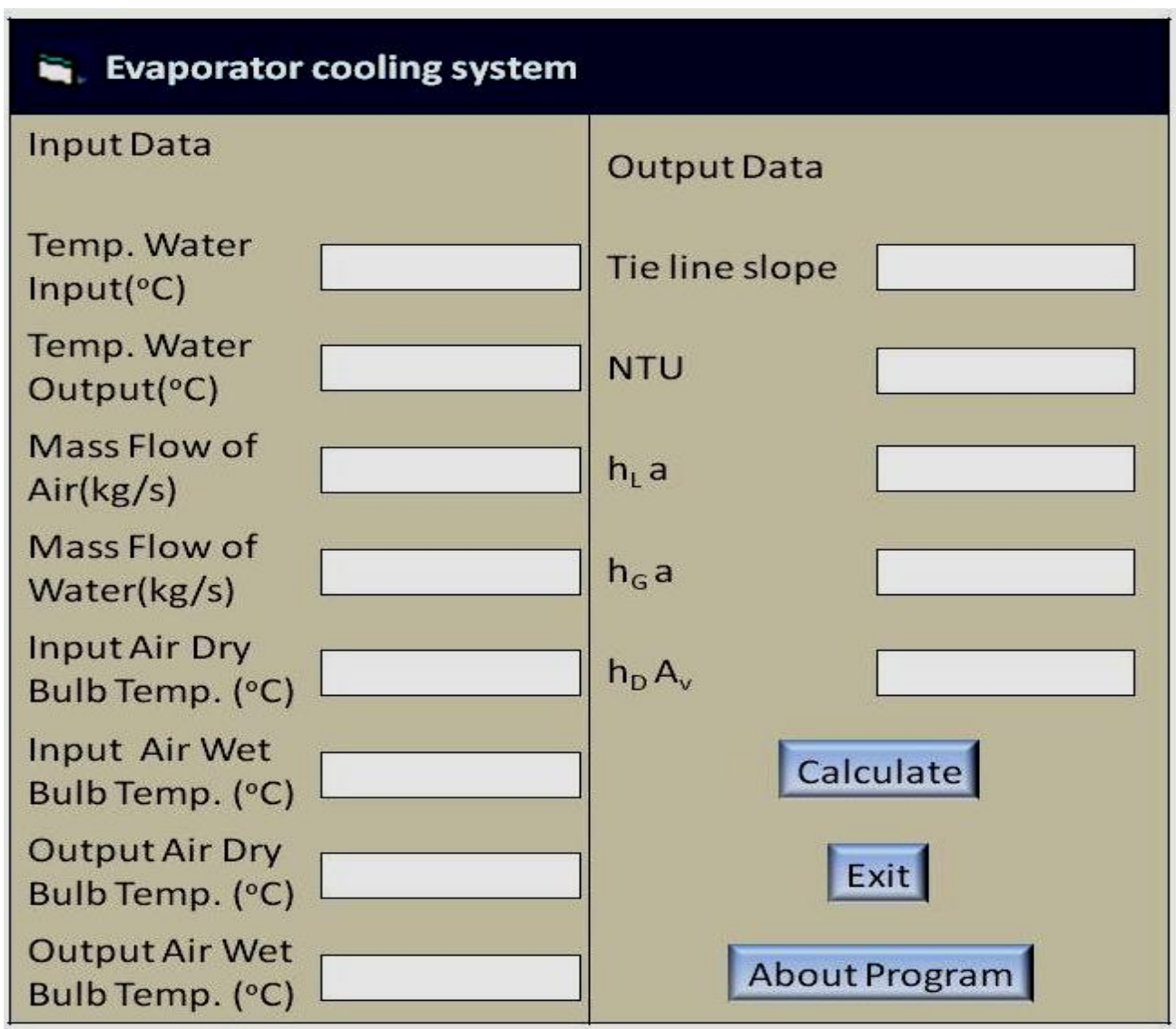

Fig. (5) Program to calculate number of transfer units and other functions of the open evaporative cooling system (made by visual basic version five).

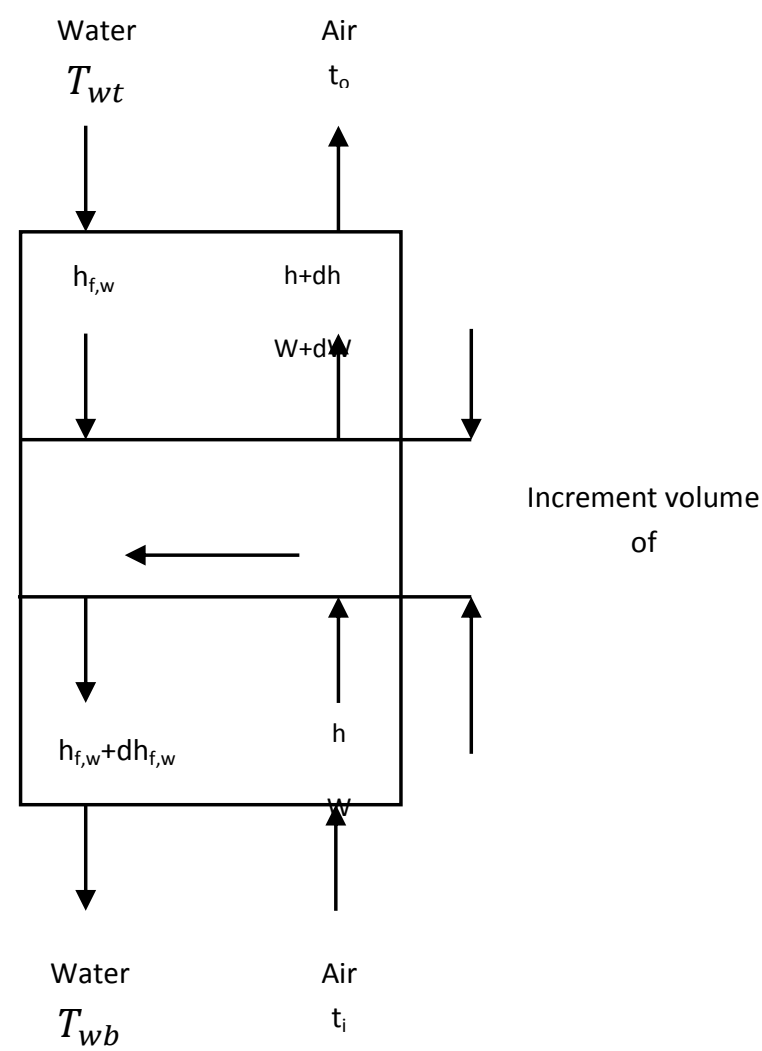

Fig. (6) Balance (energy and mass transfer) in evaporative cooling system. 
Results and Discussion :

The number of transfer unit NTU was plotted against values of water to air ratio, and shown in Figures(7, 8, 9, 10, 11, and 12), for packing at a heights of $0.7 \mathrm{~m}$ and inlet water temperature equals 318 $\mathrm{K}\left(45{ }^{\circ} \mathrm{C}\right)$. A straight shapes of parallel lines observed from these figures to fit the above data.

In general, for constant value of air mass flow rate, the larger the water to air ratio the smaller the tower characteristics. This behavior Can be attributed to fact that, increasing of water mass flow rate for constant value of air flow means an increase in heat load that in turn decreases the packing efficiency for dissipating this excess in heat load. In other words, increasing the value of $\dot{f}_{w}$ decreases the cooling range (the difference between inlet and outlet temperature).

To reveal the influence of inlet water temperature on evaporative cooling characteristics, Figs. $(13,14,15$,and 16$)$ indicate that for a fixed value of water to air ratio $\left(\dot{f_{w}} \quad / \dot{f}_{\boldsymbol{a}}\right)$, as the inlet water temperature increase the Number of transfer unit NTU will decrease. This confirms that increasing the heat load decreases the tower characteristics; The results showed that the decreasing in Number of transfer unit NTU on average only about $(14 \%)$ for each $\left(10{ }^{\circ} \mathrm{C}\right)$ increase in inlet water temperature .

The effect of inlet water temperature associated with mass flow of air $\dot{f}_{\boldsymbol{a}}$ on volumetric mass transfer coefficient $\left(h_{D} A_{V}\right)$ was shown in figure(17). It was clear that increasing the inlet temperature of water decreases the volumetric mass transfer coefficient, and this occurs due to decrease in the value of evaporative performance. On the other hand, when the value of mass flow of air increases from $0.07 \mathrm{~kg} / \mathrm{s}$ to $0.18 \mathrm{~kg} / \mathrm{s},\left(h_{D} A_{V}\right)$ increases about ( $20 \%)$, since the rate of evaporation was changing with mass flow of air .

The effect of mass flow rate of air and inlet water temperature on 
volumetric heat transfer coefficient $\left(h_{\mathrm{G}} \mathrm{a}\right)$ was entirely analogous to their effect on $\left(h_{D} A_{V}\right)$ due to Lewis relationship

$\left(\mathrm{h}_{\mathrm{G}} \mathrm{a}=\right.$ $h_{D} A_{V} \cdot \mathrm{C}_{\mathrm{s}}$ ), as shows in Fig.(18) .

Figure.(19) compares between the number of transfer units NTU in different packed heights for thermoplastic packing $T_{w t}=45{ }^{0} \mathrm{C}$. The characteristics decrease with increasing the value of water to air mass flow for constant mass flow of air. It was reported in the literature that the majority of investigators in the evaporative cooling system field have correlated the number of transfer units NTU with water to air ratio $\left(\dot{\boldsymbol{f}_{\boldsymbol{w}}} / \dot{\boldsymbol{f}}_{\boldsymbol{a}}\right)$ as follows :

The Formula equation $N T U=b_{1}\left(\frac{\dot{f_{w}}}{\dot{\boldsymbol{f}_{\boldsymbol{a}}}}\right)^{b_{2}}$ was derived for relating and showing the relation between the number of transfer units and the water to air ratio, and the program estimating the NTU and other functions(heat transfer coefficient mass transfer coefficient tie-line) against the variables of system. Each curve in Fig.(19) can be expressed in a form of equation $N T U=b_{1}\left(\frac{\dot{f_{w}}}{\dot{f_{\boldsymbol{a}}}}\right)^{b_{2}}$. Thus twelve number of transfer units, were shown in Table (1) :

The magnitude of find effects, is shown in Figs. $(20,21$, and 22 ). It is determined and tested at various heights with constant value of airflow. The value of tower characteristic for end effects gained upon extrapolation to Zero height; hence an intercept on the vertical axis will give the value of $N T U_{\text {eq. }}$ ,the number of transfer units corresponding to end effects only which will be subtracted from the value of uncorrected tower characteristics NTU; while the intercept with the horizontal axis correspond to the negative value of ( $\mathrm{Z}_{\mathrm{eq}}$ ), the equivalent height of end effects . 
Table (1): $N T U_{\text {Uncorr. }}$ equations for thermoplastic counter current wavy packing .

\begin{tabular}{|c|c|c|c|}
\hline \multirow{2}{*}{ Height (m) } & Mass flow of air $0.07 \mathrm{~kg} / \mathrm{s}$ & Mass flow of air $0.125 \mathrm{~kg} / \mathrm{s}$ & Mass flow of air $0.18 \mathrm{~kg} / \mathrm{s}$ \\
\hline & \multicolumn{3}{|c|}{ Number of transfer unit without corrected end effect } \\
\hline 1.4 & $N T U=0.466\left(\dot{\boldsymbol{f}_{\boldsymbol{w}}} / \dot{\boldsymbol{f}_{\boldsymbol{a}}}\right)^{-0.551}$ & $N T U=0.485\left(\dot{\boldsymbol{f}_{\boldsymbol{w}}} / \dot{\boldsymbol{f}_{\boldsymbol{a}}}\right)^{-0.87}$ & $N T U=0.555\left(\dot{\boldsymbol{f}_{\boldsymbol{w}}} / \dot{\boldsymbol{f}_{\boldsymbol{a}}}\right)^{-0.47}$ \\
\hline 1.05 & $N T U=0.422\left(\dot{\boldsymbol{f}_{\boldsymbol{w}}} / \dot{\boldsymbol{f}}_{\boldsymbol{a}}\right)^{-0.51}$ & $N T U=0.433\left(\dot{\boldsymbol{f}_{\boldsymbol{w}}} / \dot{\boldsymbol{f}}_{\boldsymbol{a}}\right)^{-0.84}$ & $N T U=0.549\left(\dot{\boldsymbol{f}_{\boldsymbol{w}}} / \dot{\boldsymbol{f}_{\boldsymbol{a}}}\right)^{-0.723}$ \\
\hline 0.7 & $N T U=0.3891\left(\dot{\boldsymbol{f}_{\boldsymbol{w}}} / \dot{\boldsymbol{f}}_{\boldsymbol{a}}\right)^{-0.48}$ & $N T U=0.422\left(\dot{\boldsymbol{f}_{\boldsymbol{w}}} / \dot{\boldsymbol{f}}_{\boldsymbol{a}}\right)^{-0.79}$ & $N T U=0.491\left(\dot{\boldsymbol{f}_{\boldsymbol{w}}} / \dot{\boldsymbol{f}_{\boldsymbol{a}}}\right)^{-0.771}$ \\
\hline 0.35 & $N T U=0.286\left(\dot{\boldsymbol{f}_{\boldsymbol{w}}} / \dot{\boldsymbol{f}}_{\boldsymbol{a}}\right)^{-0.44}$ & $N T U=0.317\left(\dot{\boldsymbol{f}_{\boldsymbol{w}}} / \dot{\boldsymbol{f}}_{\boldsymbol{a}}\right)^{-0.76}$ & $N T U=0.398\left(\dot{\boldsymbol{f}_{\boldsymbol{w}}} / \dot{\boldsymbol{f}}_{\boldsymbol{a}}\right)^{-0.58}$ \\
\hline
\end{tabular}

A comparison was conducted between number of transfer unit NTU at different height of packing, after excluding the values of end effects(corrected), as can be notice in figure (23) .

As for counter current wavy thermoplastic packing

$$
\frac{N T U}{Z}=0.42 \dot{\boldsymbol{f}}_{\boldsymbol{w}}^{-0.66} \dot{\boldsymbol{f}}_{\boldsymbol{a}}^{0.55}
$$

For saddle thermoplastic packing

$$
\frac{N T U}{Z}=0.24 \dot{\boldsymbol{f}}_{\boldsymbol{w}}^{-0.77} \dot{\boldsymbol{f}}_{\boldsymbol{a}}^{0.39}
$$

For triangular thermoplastic packing

$$
\frac{N T U}{Z}=0.32 \dot{f}_{\boldsymbol{w}}^{-0.81} \dot{\boldsymbol{f}}_{\boldsymbol{a}}{ }^{0.45}
$$

For triangular wood packing

$$
\frac{N T U}{Z}=0.11 \dot{\boldsymbol{f}}_{\boldsymbol{w}}^{-0.88} \dot{\boldsymbol{f}}_{\boldsymbol{a}}^{0.39}
$$

For saddle glass packing

$$
\frac{N T U}{Z}=0.42 \dot{f}_{w}^{-0.66} \dot{f}_{a}^{0.55}
$$

For triangular glass packing

$$
\frac{N T U}{Z}=0.31 \dot{\boldsymbol{f}}_{\boldsymbol{w}}^{-0.77} \dot{\boldsymbol{f}}_{\boldsymbol{a}}^{0.45}
$$


The relation between the values of Tie-line slope and the flow of Water and air can be shown in figure (24). Examining the curves in figure (24) gives as full believes that the changing in tie-line with types of packing was not happen, while the changing in the values of liquid flow were very effectives on the tie-line at different condition. The equations from fifty-one to twenty show the relations between Tie-line and fluids flow.

Tie- line slope $=194 \dot{\boldsymbol{f}}_{\boldsymbol{w}}^{1.294} \dot{\boldsymbol{f}}_{\boldsymbol{a}}^{0.06}$

(Counter current wavy thermoplastic

packing)

Tie - line slope $=190 \dot{\boldsymbol{f}}_{\boldsymbol{w}}{ }^{1.263} \dot{\boldsymbol{f}}_{\boldsymbol{a}}{ }^{0.059}$

(Saddle thermoplastic packing)

Tie- line slope $=203 \dot{\boldsymbol{f}}_{\boldsymbol{w}}^{1.39} \dot{\boldsymbol{f}}_{\boldsymbol{a}}{ }^{0.062}$

( Triangular thermoplastic packing)

Tie- line slope $=179 \dot{\boldsymbol{f}}_{\boldsymbol{w}}^{1.225} \dot{\boldsymbol{f}}_{\boldsymbol{a}}^{0.074}$

(Triangular wood packing)

Tie- line slope $=191 \dot{\boldsymbol{f}}_{\boldsymbol{w}}^{1.183} \dot{\boldsymbol{f}}_{\boldsymbol{a}}^{0.059}$

(Saddle glass packing)

Tie - line slope $=188 \dot{\boldsymbol{f}}_{\boldsymbol{w}}{ }^{1.21} \dot{\boldsymbol{f}}_{\boldsymbol{a}}{ }^{0.058}$

(Triangular glass packing)

Since the liquid side heat, transfer coefficient is a function of tie line slope. The liquid side heat transfer coefficient, $\left(h_{L} a\right)$, can be shown is Figure(25). The values of liquid side heat transfer coefficients affecting very well with the types of packing. The equations from fifty-one to twenty show the relations between the liquid side heat transfer coefficient and types of packing.

$\mathrm{h}_{\mathrm{L}} \mathrm{a}=1535 \dot{\boldsymbol{f}}_{\boldsymbol{w}}^{1.53} \dot{\boldsymbol{f}}_{\boldsymbol{a}}^{0.54}$

Counter current wavy thermoplastic

$\mathrm{h}_{\mathrm{L}} \mathrm{a}=1557 \dot{\boldsymbol{f}}_{\boldsymbol{w}}^{1.55} \dot{\boldsymbol{f}}_{\boldsymbol{a}}^{0.53}$

Saddle thermoplastic packing 
$\mathrm{h}_{\mathrm{L}} \mathrm{a}=1478 \dot{\boldsymbol{f}}_{\boldsymbol{w}}{ }^{1.47} \dot{\boldsymbol{f}}_{\boldsymbol{a}}{ }^{0.63}$

Triangular thermoplastic packing

$\mathrm{h}_{\mathrm{L}} \mathrm{a}=1451 \dot{\boldsymbol{f}}_{\boldsymbol{w}}^{1.61} \dot{\boldsymbol{f}}_{\boldsymbol{a}}^{0.58}$

Triangular wood packing

$\mathrm{h}_{\mathrm{L}} \mathrm{a}=1870 \dot{\boldsymbol{f}}_{\boldsymbol{w}}^{1.59} \dot{\boldsymbol{f}}_{\boldsymbol{a}}^{0.55}$

Saddle glass packing

$\mathrm{h}_{\mathrm{L}} \mathrm{a}=1182 \dot{\boldsymbol{f}}_{\boldsymbol{w}}{ }^{1.62} \dot{\boldsymbol{f}}_{\boldsymbol{a}}{ }^{0.49}$

Triangular glass packing

The temperatures distribution and profile along the evaporator at different inlet water temperatures and air conditions and at different types of packing were a function of evaporator height and not a function of fluids mass flow.

The temperatures distribution and profile in the first layer was not goods much, this happened because the distribution of water in the packing surface was just know happened, while in the other layers the temperature distribution and profile were so good and perfect. 


\section{Conclusion:}

1. The results showed that the thermoplastic packing was much more efficient than glass and wood by efficiency about 12 to $18 \%$.

2. The results showed that the triangular packing was much more efficient than wavy and glass by efficiency about 5 to 11 $\%$.

3. The effects of water and air mass flow rates were investigate on the uncorrected number of transfer units. The effects of water and air mass flow rates were investigate on the corrected number of transfer units through excluding the effecting of end effect (the height of evaporator without fill) of cooling evaporator.

4. From the results, we can notice that at maximum air mass flow and minimum water mass flow, the mass transfer coefficients would be on the maximum value and vice-versa.

5. A maximum air mass flow and minimum water mass flow, the heat transfer coefficients would be on the maximum value and vice-versa.

6. The heat transfer coefficients changing with water mass flow greater than the changing with air mass flow by about $26 \%$.

7. The temperatures distribution were not constant in all layers, in the first layer was not goods much, this happened because the distribution of water in the packing surface was just know happened, while in the other layers the temperature distribution and profile were so good and perfect.

8. A visual basic program(version five) was made-up to calculate the mass transfer coefficients, heat transfer coefficients, number of transfer coefficient, and tie-line slope). 


\section{Nomenclature:}

1A,1B,1C .....16A,16B,16C : Labels of thermocouples.

$\dot{\boldsymbol{f}_{\boldsymbol{a}}} \quad$ :mass flow of air $\mathrm{kg} / \mathrm{s}$

$\dot{f_{w}} \quad:$ mass flow of water $\mathrm{kg} / \mathrm{s}$

$\mathrm{CP}_{\mathrm{a}} \quad$ :Specific heat at constant pressure of moist air kJ/kg.K

$\mathrm{h} \quad$ :Enthalpy of moist air $\mathrm{kJ} / \mathrm{kg}$

$\mathrm{h}_{\mathrm{c}} \quad$ :Heat transfer coefficient of air $\mathrm{kW} / \mathrm{m}^{2} . \mathrm{K}$

$\mathrm{h}_{\mathrm{c}, \mathrm{w}} \quad$ :Heat transfer coefficient of water $\mathrm{kW} / \mathrm{m}^{2} . \mathrm{K}$

$\mathrm{h}_{\mathrm{f}, \mathrm{w}} \quad$ :Enthalpy of water at $\mathrm{t}_{\mathrm{w}} \mathrm{kJ} / \mathrm{kg}$

$\mathrm{h}_{\mathrm{fg}, \mathrm{w}} \quad$ :Change of phase enthalpy

Le :Lewis number

$\mathrm{h}_{\mathrm{G}} \mathrm{a} \quad$ :Heat transfer coefficient in gas phase $\mathrm{kw} / \mathrm{m}^{3} . \mathrm{k}$.

$h_{D} \quad:$ Mass transfer coefficient $\mathrm{kg} / \mathrm{s} . \mathrm{m}^{2}$

$\mathrm{h}_{\mathrm{L}}$ a $\quad:$ Heat transfer coefficient in liquid phase $\mathrm{kw} / \mathrm{m}^{3} . \mathrm{k}$.

$\mathrm{t} \quad$ :Dry bulb temperature of air $\mathrm{C}^{\mathrm{o}}$.

$T_{w t} \quad$ :Temperature of water at top of packing .

$T_{w b} \quad$ :Temperature of water at bottom of packing . 


\section{References:}

1. J.C.Kloppers, D.G.Krger. A critical investigation into the heat and mass transfer analysis of counter flow wet-cooling towers. International Journal of Heat and Mass Transfer, 2005, 48,765-777.

2. N. Williamson, S. Armfield, M. Behnia. Numerical simulation of flow in a natural draft wet cooling tower - the effect of radial thermo-fluid fields. Applied Thermal Engineering, 2008, 28(2-3), 178-189.

3. T. Muangnoi, W. Asvapoositkul, S. Wongwises . An exergy analysis on the performance of a counter flow wet cooling tower. Applied Thermal Engineering 2007, 27, 910-917.

4. M. Gao, F.Z. Sun, K. Wang, et al.. Experimental research of heat transfer performance on natural draft counter flow wet cooling tower under cross-wind conditions. International Journal of Thermal Sciences , 2008,47, (7), ,935-941.

5. A. Hasan and K. Siren. Theoretical and Computational Analysis of Closed Wet Cooling Towers and Its Applications in Cooling of Buildings. Energy and Building, 2002, 34,5 ,477-486.

6. G. Gan, S. B. Riffat, L. Shao and P. Doherty. Application of CFD to closed wet cooling towers for use with chilled ceilings. Applied Thermal Engineering,2001, 21, 1.

7. S. Fisenko, A. Petruchik and A. Solodukhim. Evaporative cooling of water in a natural draft cooling tower. Int. J. of Heat and Mass Transfer, 2002, 45, 23.

8. S. Fisenko, A. Brin and A. Petruchik. Evaporative cooling of water in a mechanical draft cooling tower. Int. J. of Heat and Mass Transfer, 2004, 47, 1

9. J. Facao and A. Oliveira. Thermal behaviour of closed wet cooling towers for use with chilled ceilings. Applied Thermal Engineering, 2000, 20, 1225.

10. P. Stabat and D. Marchio. Simplified model for indirect contact evaporative cooling tower behavior. Applied Energy, 2004, 78, 433. 
11. Seong-Yeon Yoo, Jin-Hyuck Kim, and Kyu-Hyun Han. Journal of Mechanical Science and Technology 2010, 24, 893 898.

12. Jameel-Ur-Rehman Khan, Bilal Ahmed Qureshi,and Syed M. Zubair. A comprehensive design and performance evaluation study of counter flow wet cooling towers. International Journal of Refrigeration 2004, 27, 914-923.

13. M. Lucas , P.J. Martnez a, and A. Viedma. Experimental study on the thermal performance of a mechanical cooling tower with different drift eliminators. Energy Conversion and Management 2009, 50, 490-497.

14. N. Williamson a, M. Behnia , and S. Armfield. Comparison of a 2D axisymmetric CFD model of a natural draft wet cooling tower and a 1D model. International Journal of Heat and Mass Transfer 2008, 51, 2227-2236.

15. Thirapong Muangnoi, Wanchai Asvapoositkul ,and Somchai Wongwises .An exergy analysis on the performance of a counter flow wet cooling tower. Applied Thermal Engineering 2007, 27, 910.

16. ASHRAE equipment guide, 1983,ch.3.

17. El-Dessouky Hi and el.at. .A modified analysis of countre flow cooling towers. ASME J. Heat transfer ,1997,119,3. 


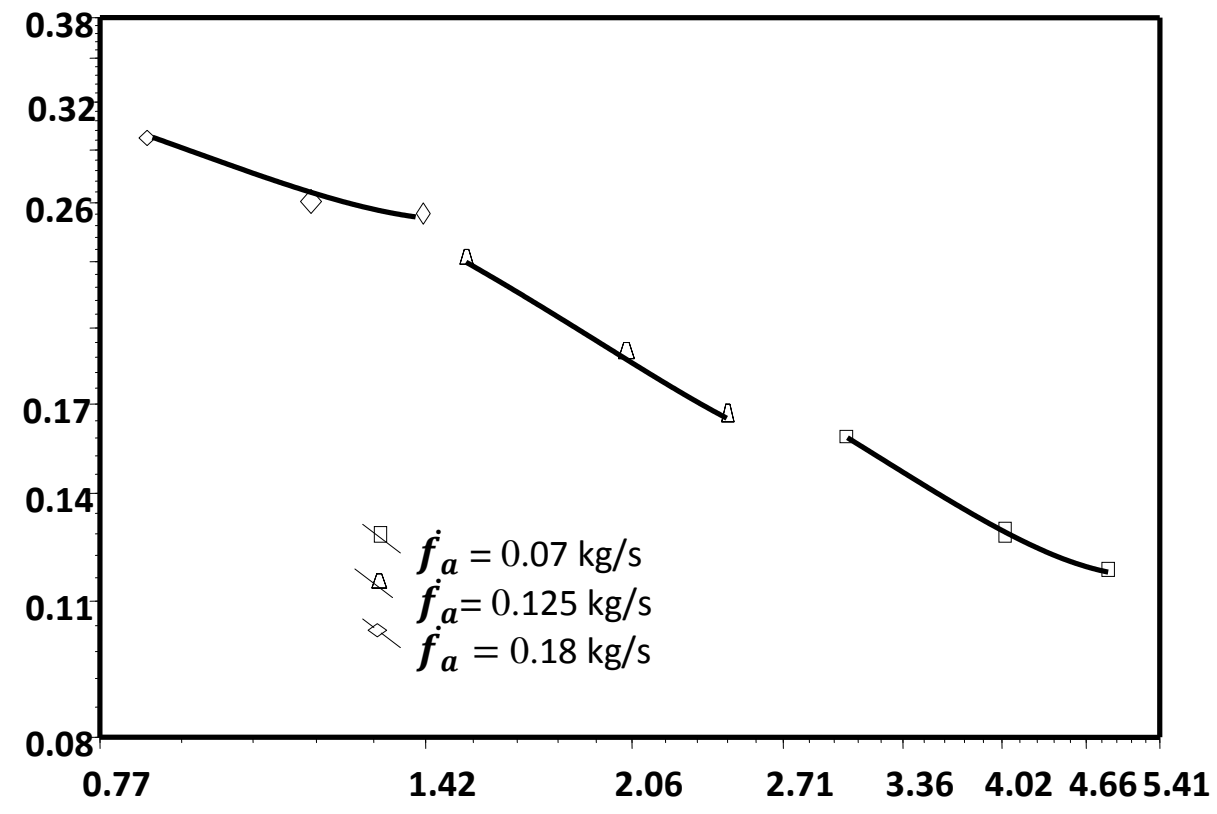

Fig. ( 7) Uncorrected NTU vs. $\dot{f_{w}} / \dot{f}_{a}$ for counter current wavy thermoplastic packing, $T_{w t}=45^{\circ} \mathrm{C}$ and packing height $=0.7 \mathrm{~m}$.

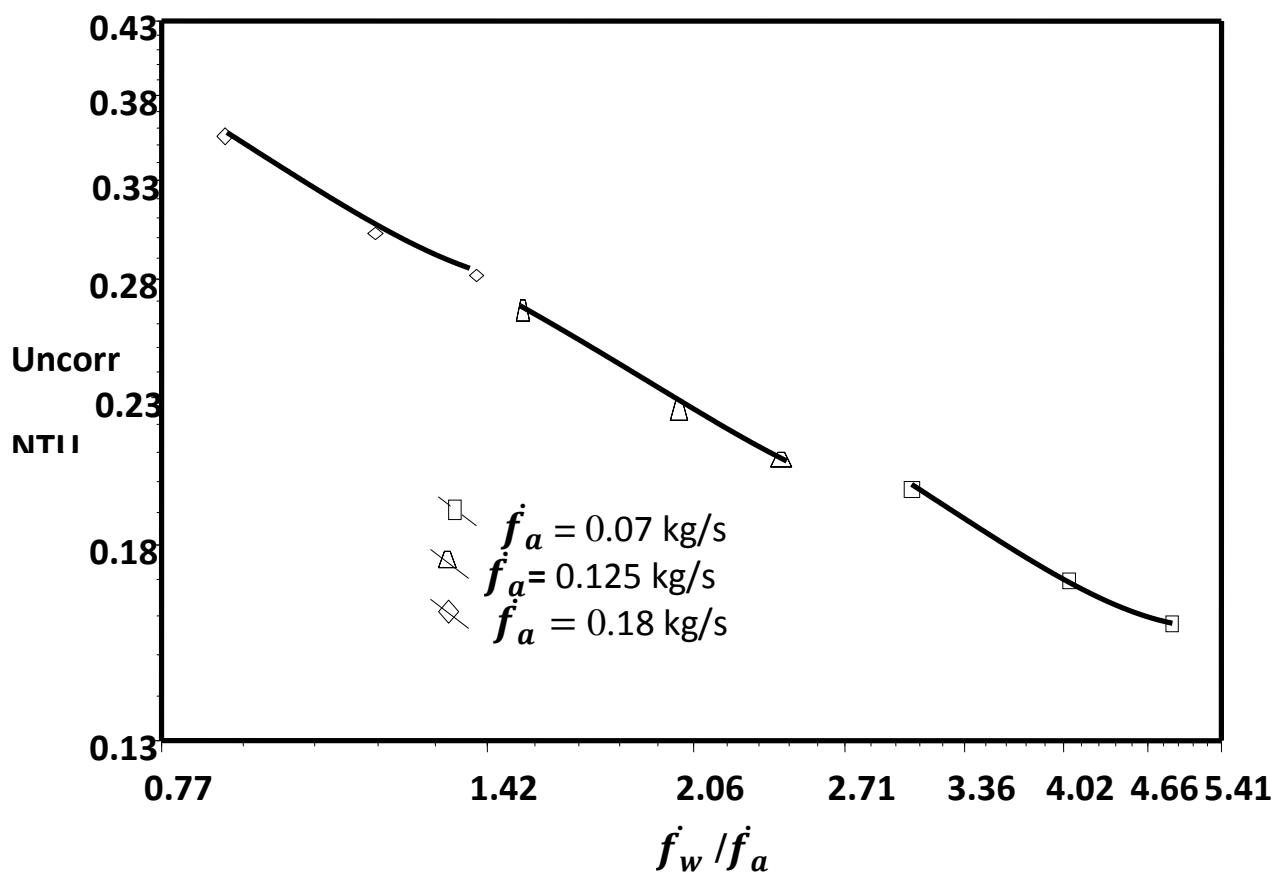

Fig.(8) Uncorrected NTU vs. $\dot{f_{w}} / \dot{f}_{a}$ for saddle thermoplastic packing, $T_{w t}=45^{\circ} \mathrm{C}$ , and packing height $=0.7 \mathrm{~m}$. 


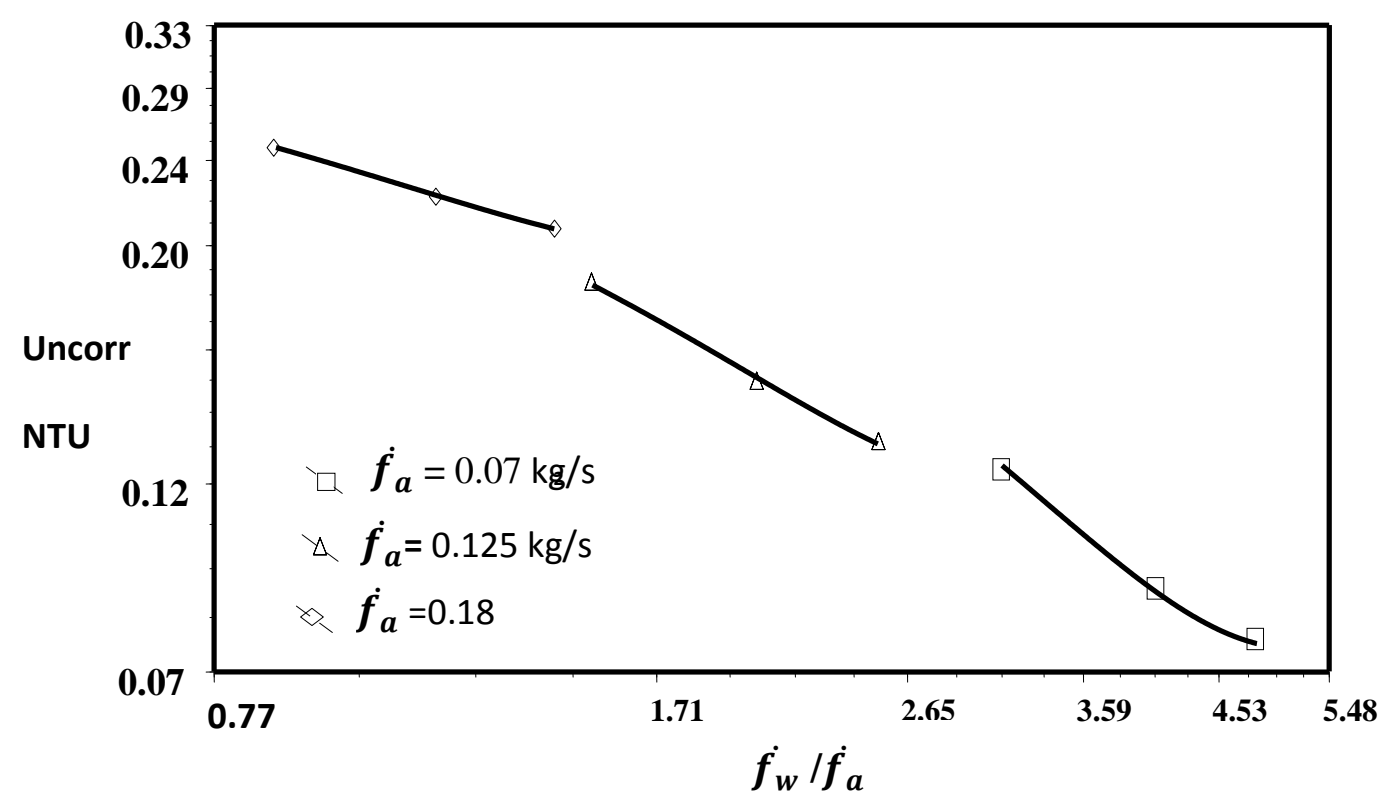

Fig.(9) Uncorr. NTU vs. $\dot{f_{w}} / \dot{f}_{a}$ for triangular thermoplastic pack, $T_{w t}=45^{\circ} \mathrm{C}$, and packing height $=\mathbf{0 . 7} \mathbf{~ m}$.

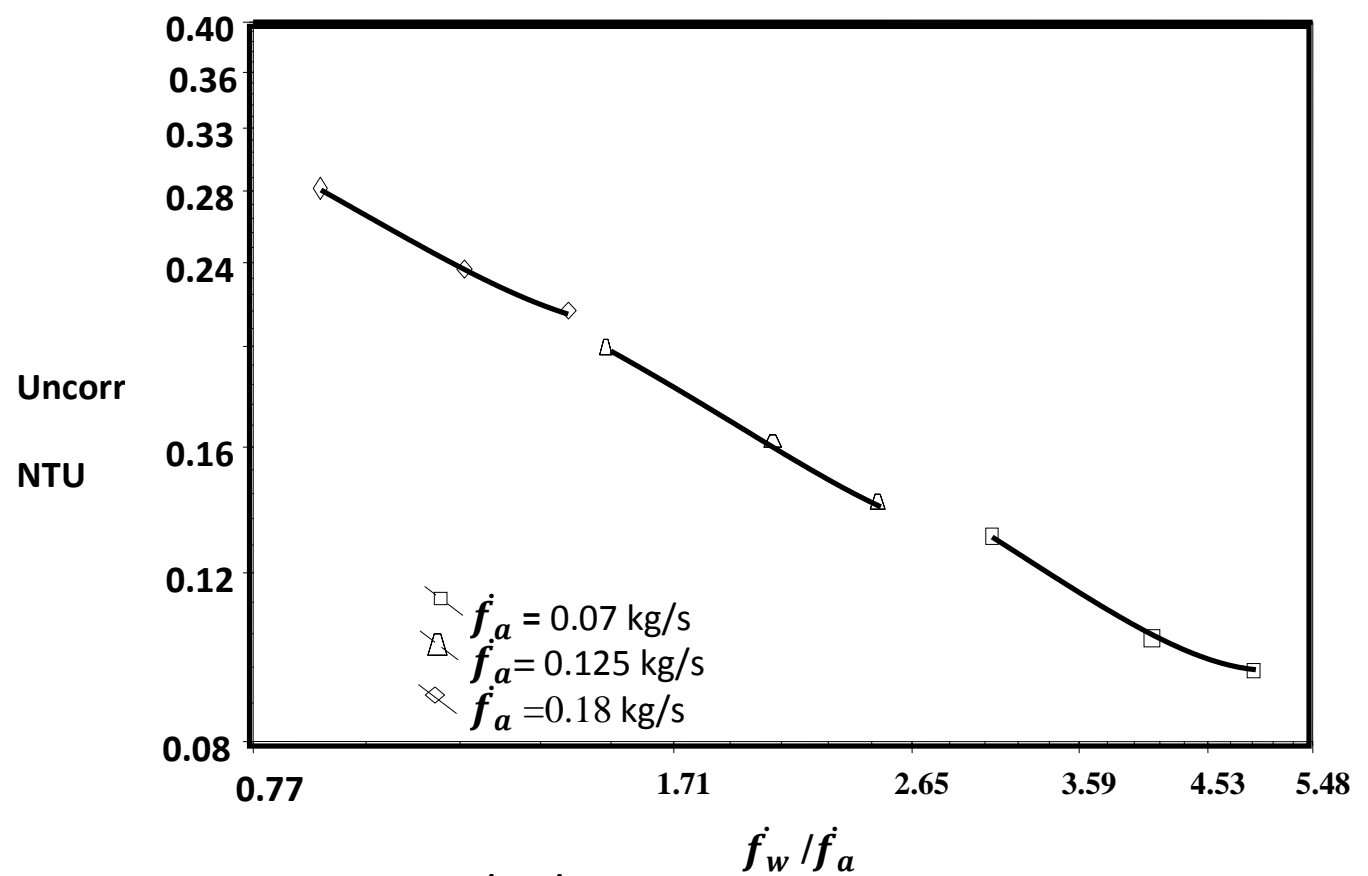

Fig.(10) Uncorr. NTU vs $. \dot{f_{w}} / \dot{f_{a}}$ for triangular wood packing $T_{w t}=45^{\circ} \mathrm{C}$, and packing height $=0.7 \mathrm{~m}$. 


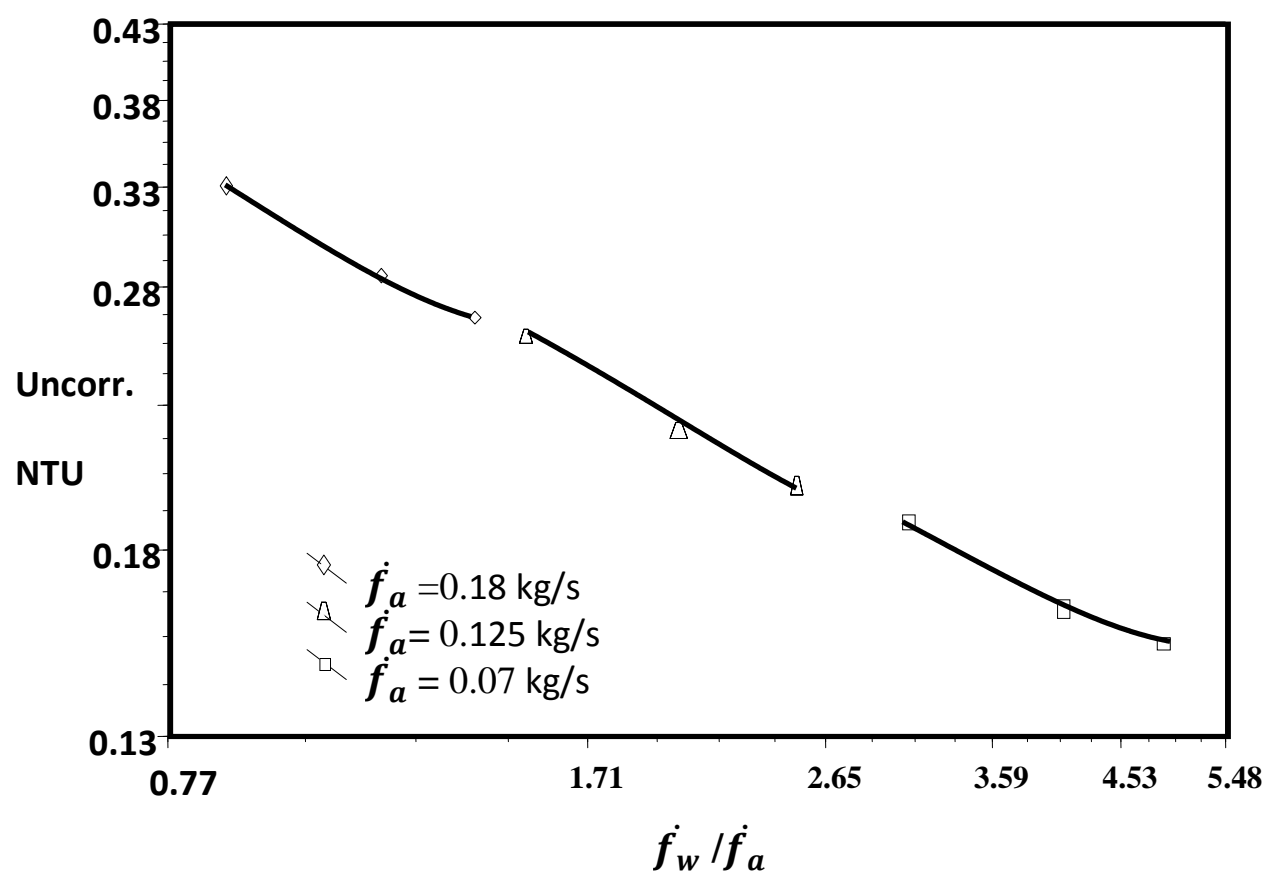

Fig.(11) Uncorr. NTU vs. $\dot{f}_{w} / \dot{f}_{a}$ for saddle glass packing, $T_{w t}=45^{\circ} \mathrm{C}$, and packing height $=0.7 \mathrm{~m}$.

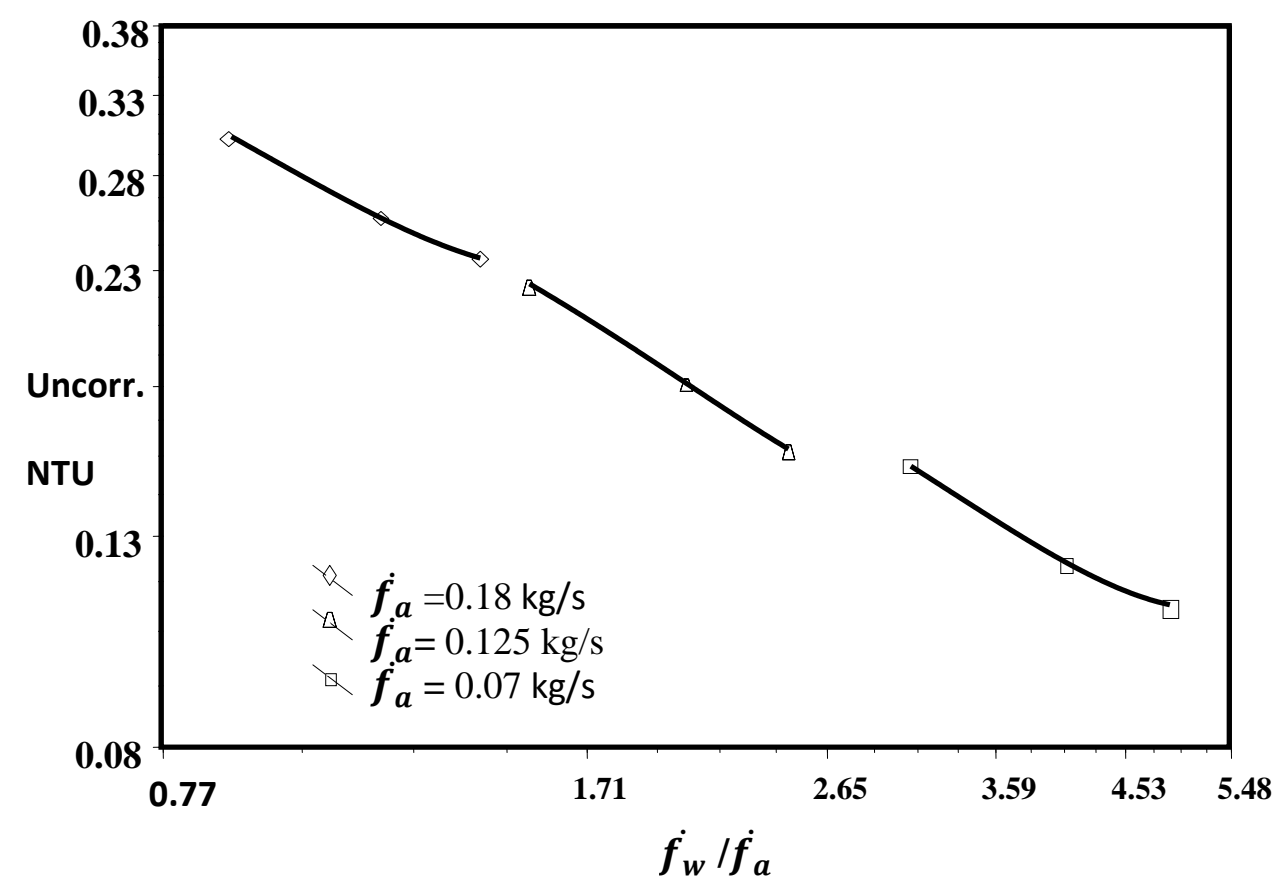

Fig.(12) Uncorr. NTU vs. $\dot{f_{w}} / \dot{f}_{a}$ for triangular glass packing, $T_{w t}=45^{\circ} \mathrm{C}$, and packing height $=0.7 \mathrm{~m}$. 


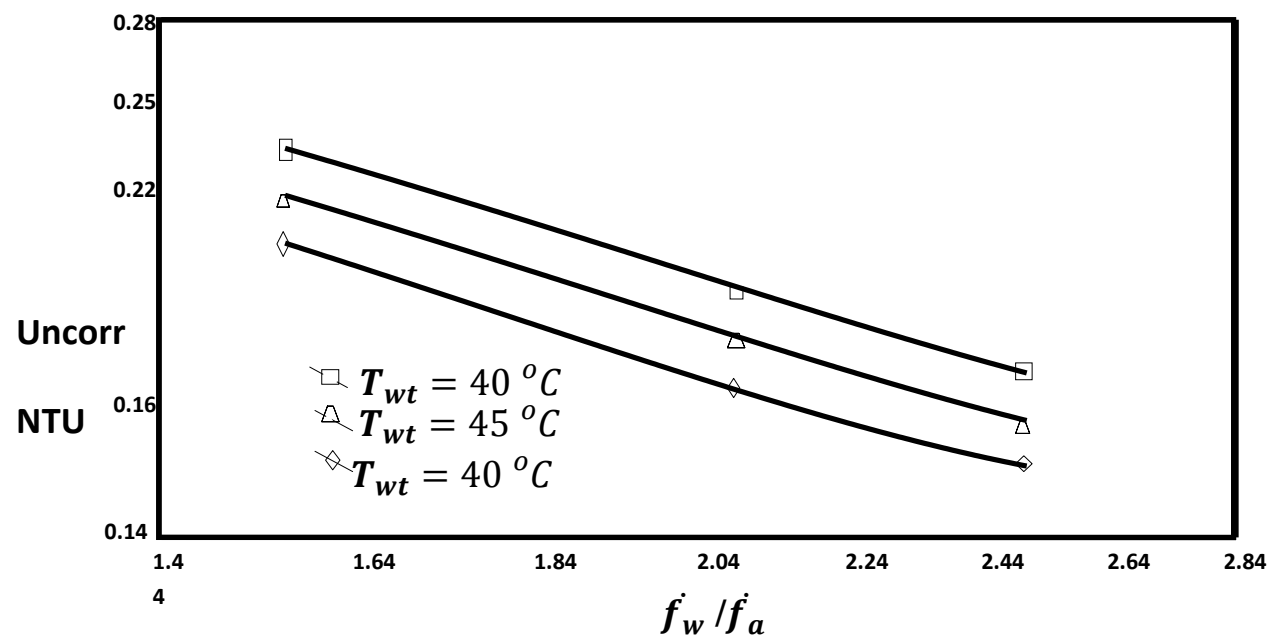

Fig.(13) Uncorr. NTU vs. $\dot{f_{w}} / \dot{f}_{a}$ for counter current wavy thermoplastic packing, $\dot{f}_{a}=0.125 \mathrm{~kg} / \mathrm{s}$, and packing height $=0.7 \mathrm{~m}$.

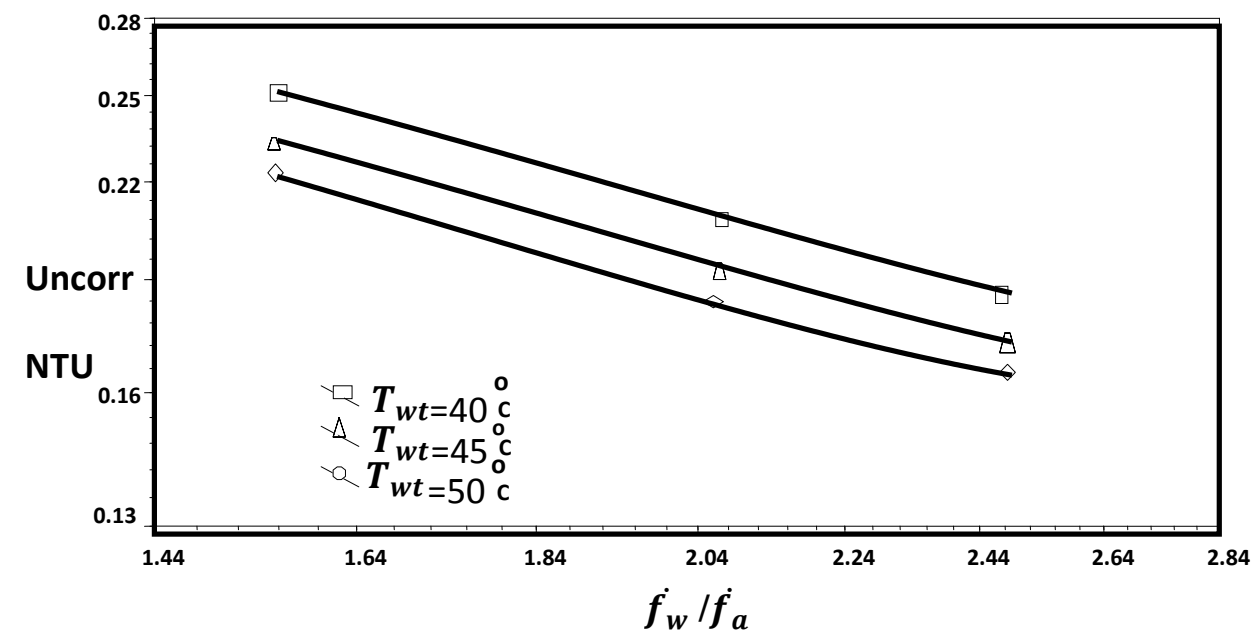

Fig.(14) Uncorr. NTU vs. $\dot{f_{w}} / \dot{f}_{a}$ for saddle thermoplastic packing, $\dot{f_{a}}=0.125 \mathrm{~kg} / \mathrm{s}$, and packing height $=0.7 \mathrm{~m}$

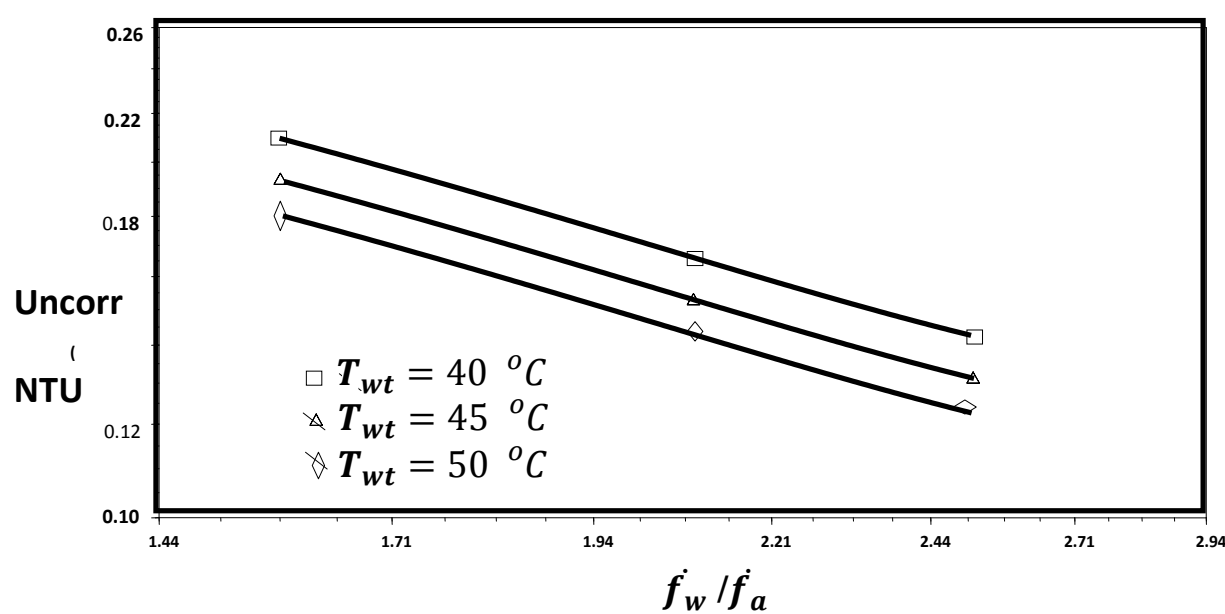

Fig.(15) Uncorr. NTU vs. $\dot{f_{w}} / \dot{f}_{a}$ for triangular thermoplastic packing, $\dot{f_{a} 0.125 ~} \mathrm{~kg} / \mathrm{s}$, and packing height $=0.7 \mathrm{~m}$. 


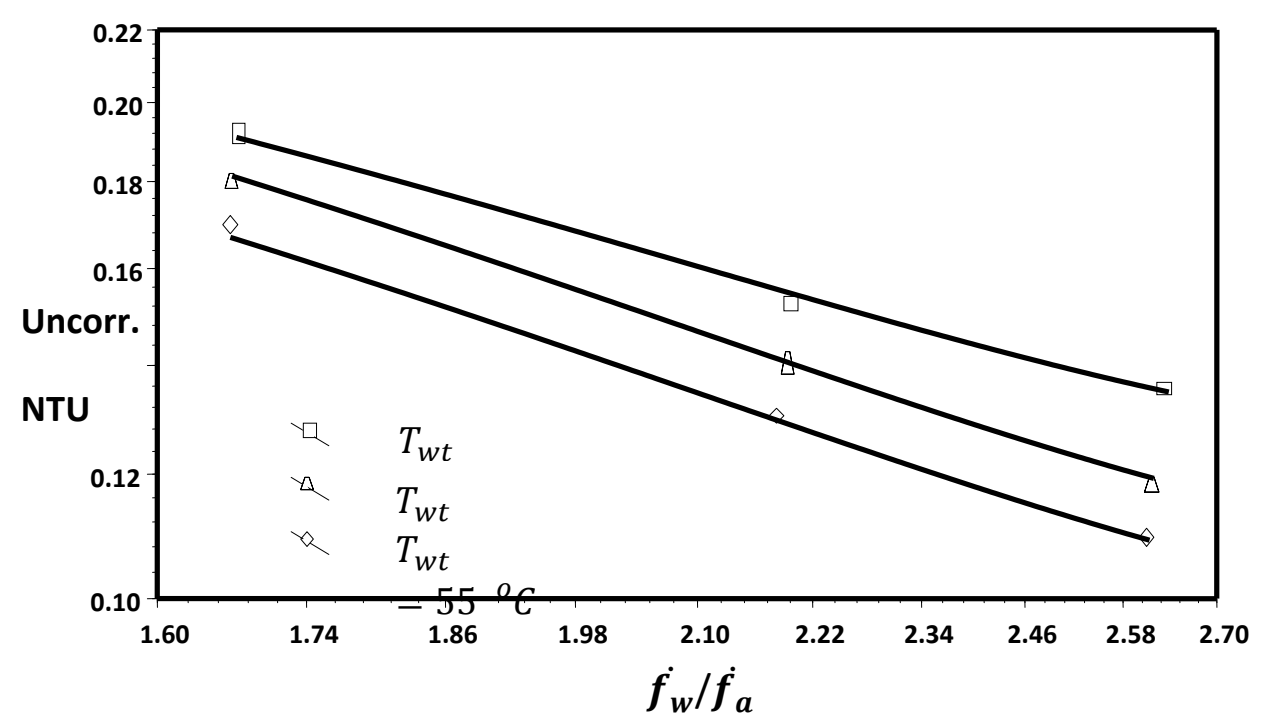

Fig.(16) Uncorr. NTU vs. $\dot{f_{w}} / \dot{f}_{a}$ for triangular wood Packing, $\dot{f}_{a}=0.125 \mathrm{~kg} / \mathrm{s}$, packing height $=0.7 \mathrm{~m}$.

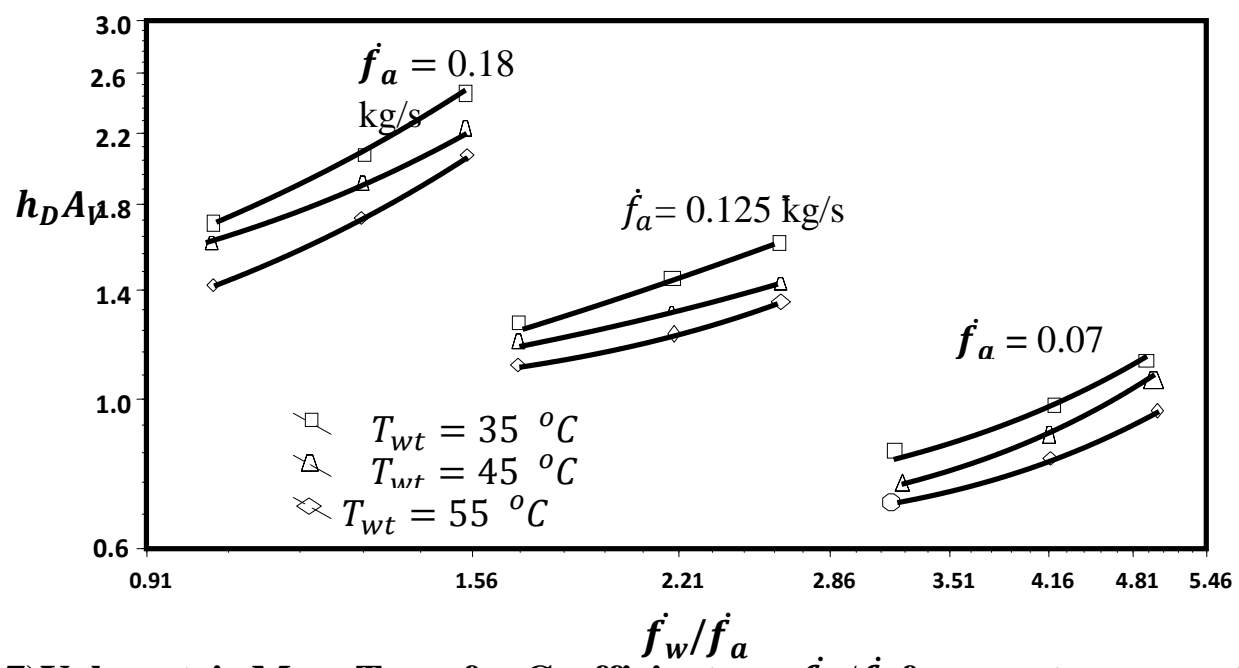

Fig.(17)Volumetric Mass Transfer Coefficient vs. $\dot{f_{w}} / \dot{f_{a}}$ for counter current wavy thermoplastic Packing, packing height $=0.7 \mathrm{~m}$.

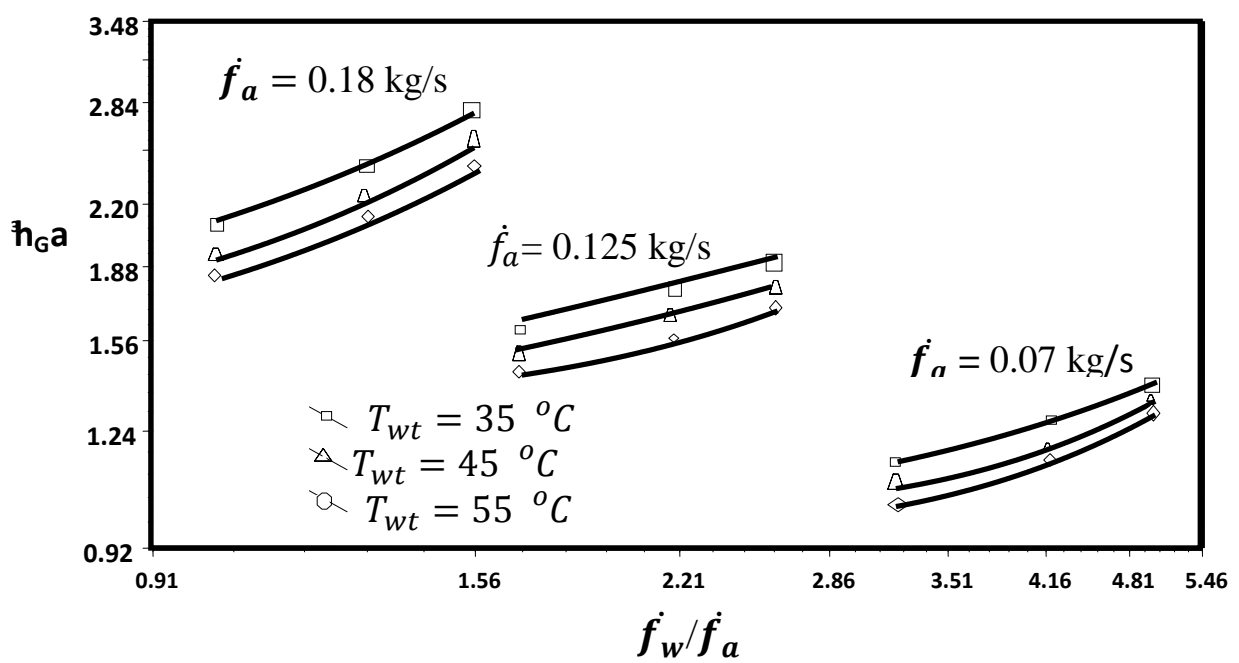

Fig.(18)Volumetric Heat Transfer Coefficient vs. $\dot{f_{w}} / \dot{f}_{a}$ for counter current wavy thermoplastic, packing height $=0.7 \mathrm{~m}$. 


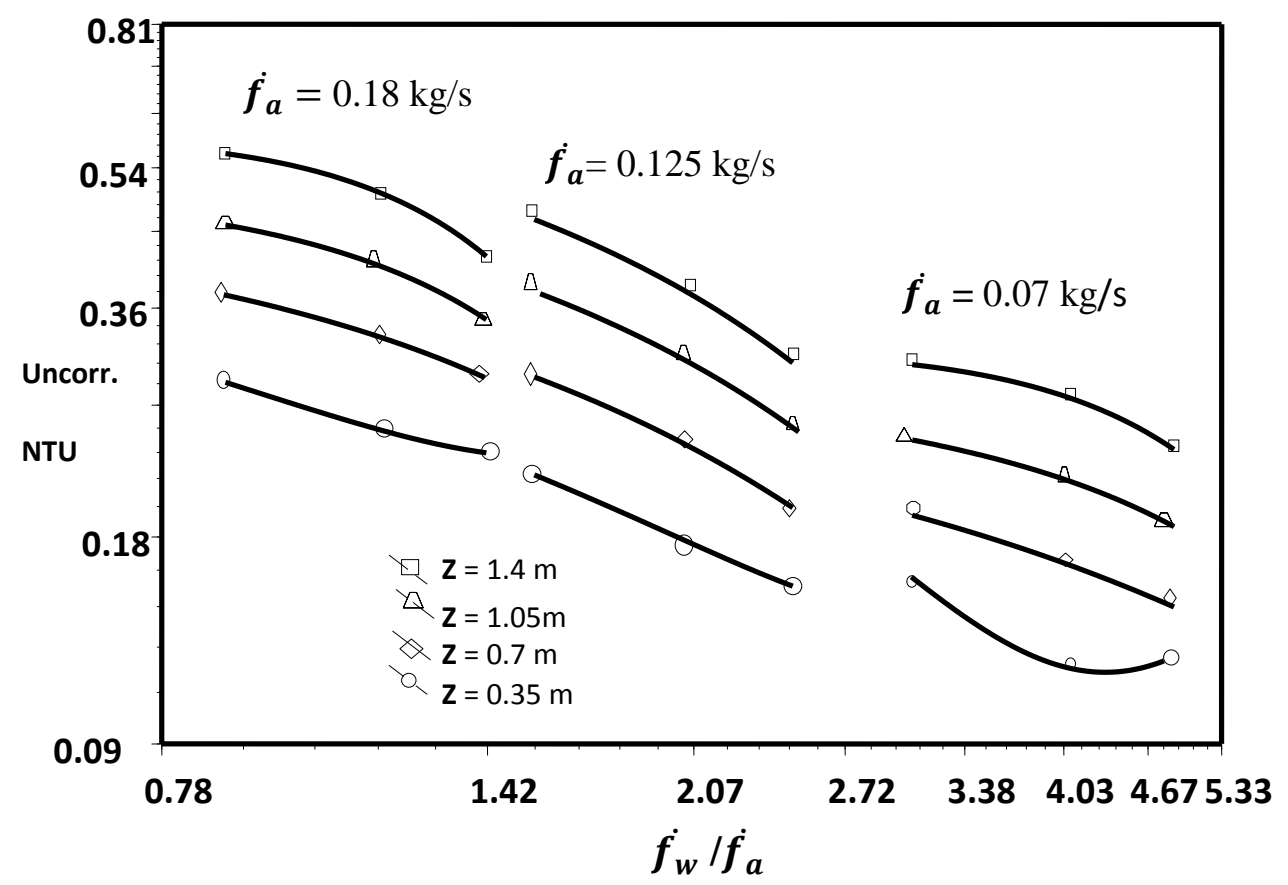

Fig.(19) Uncorr. NTU vs. $\dot{f_{w}} / \dot{f_{a}}$ for wavy thermoplastic packing, $T_{w t}=45^{0} \mathrm{C}$

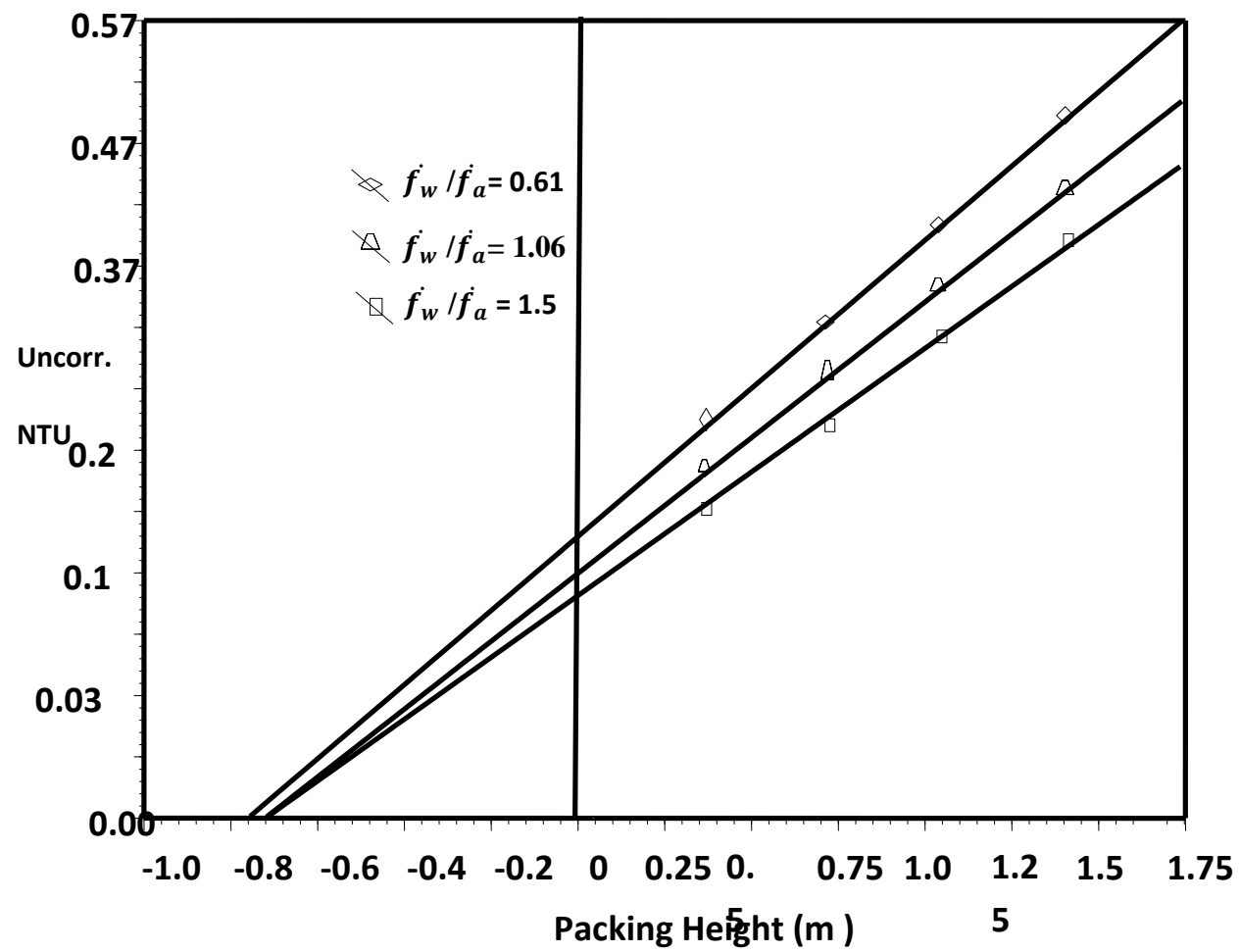

Fig.(20) Uncorr. NTU vs. Packing Height for wavy thermoplastic packing, $T_{w t}=40^{\circ} \mathrm{C}$, and $\dot{f}_{a}=0.18 \mathrm{~kg} / \mathrm{s}^{\cdot}$ 


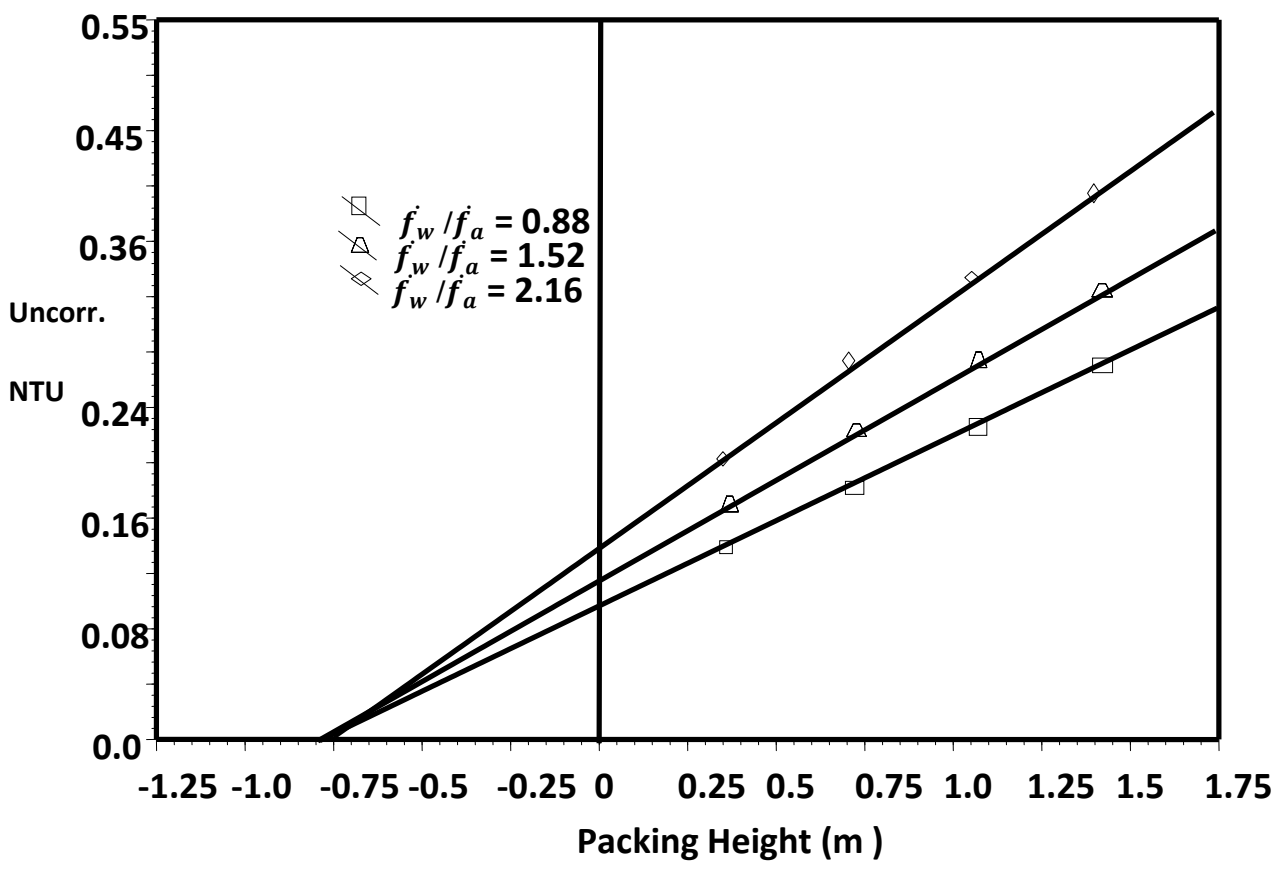

Fig.(21) Uncorr. NTU vs. Packing Height for saddle thermoplastic packing, $T_{w t}=40$ ${ }^{0} \mathrm{C}$, and $\dot{f}_{a}=0.125 \mathrm{~kg} / \mathrm{s}$

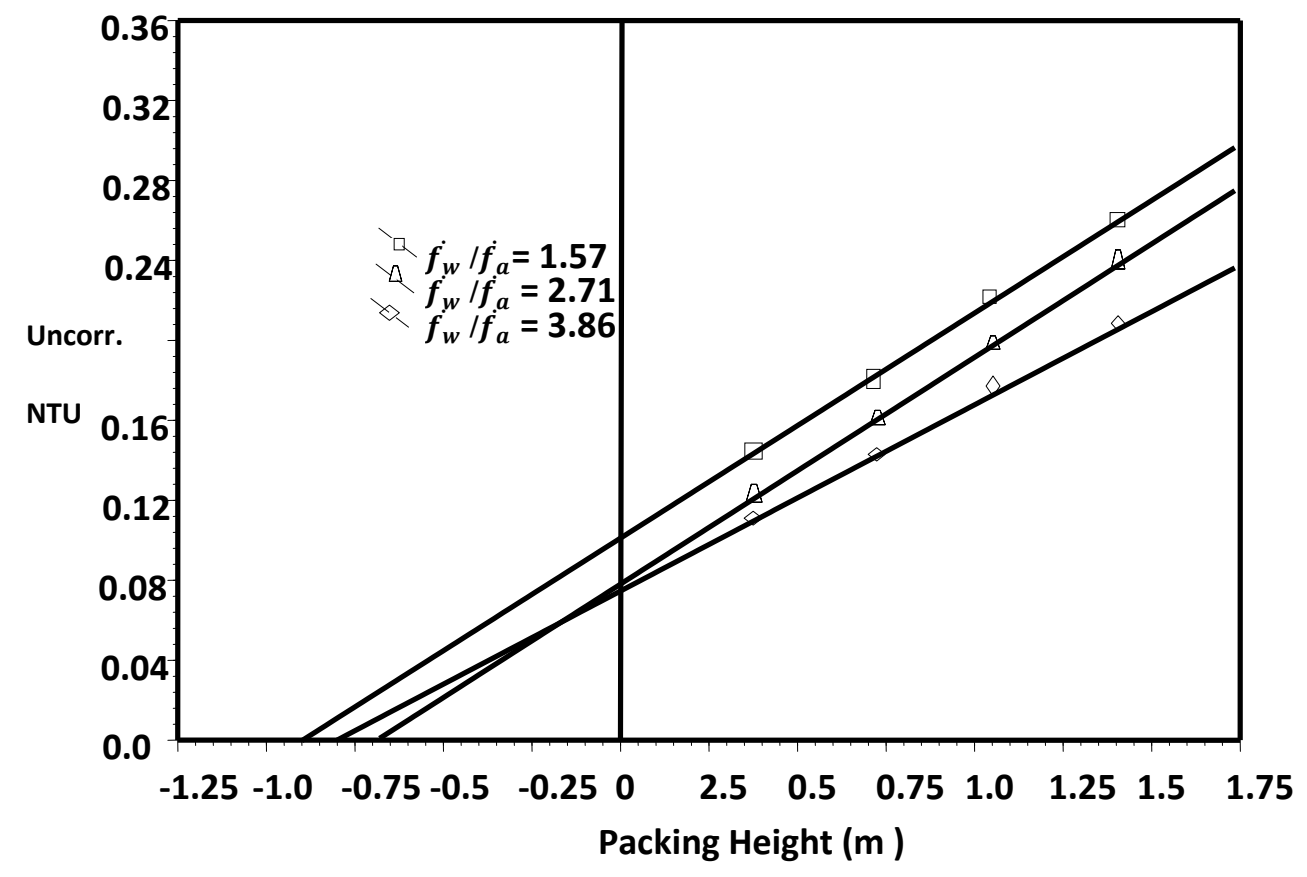

Fig.(22) Uncorr. NTU vs. Packing Height for triangular thermoplastic packing, $T_{w t}=40$ ${ }^{\circ} \mathrm{C}$, and $\dot{f_{a}}=0.07 \mathrm{~kg} / \mathrm{s}$ 


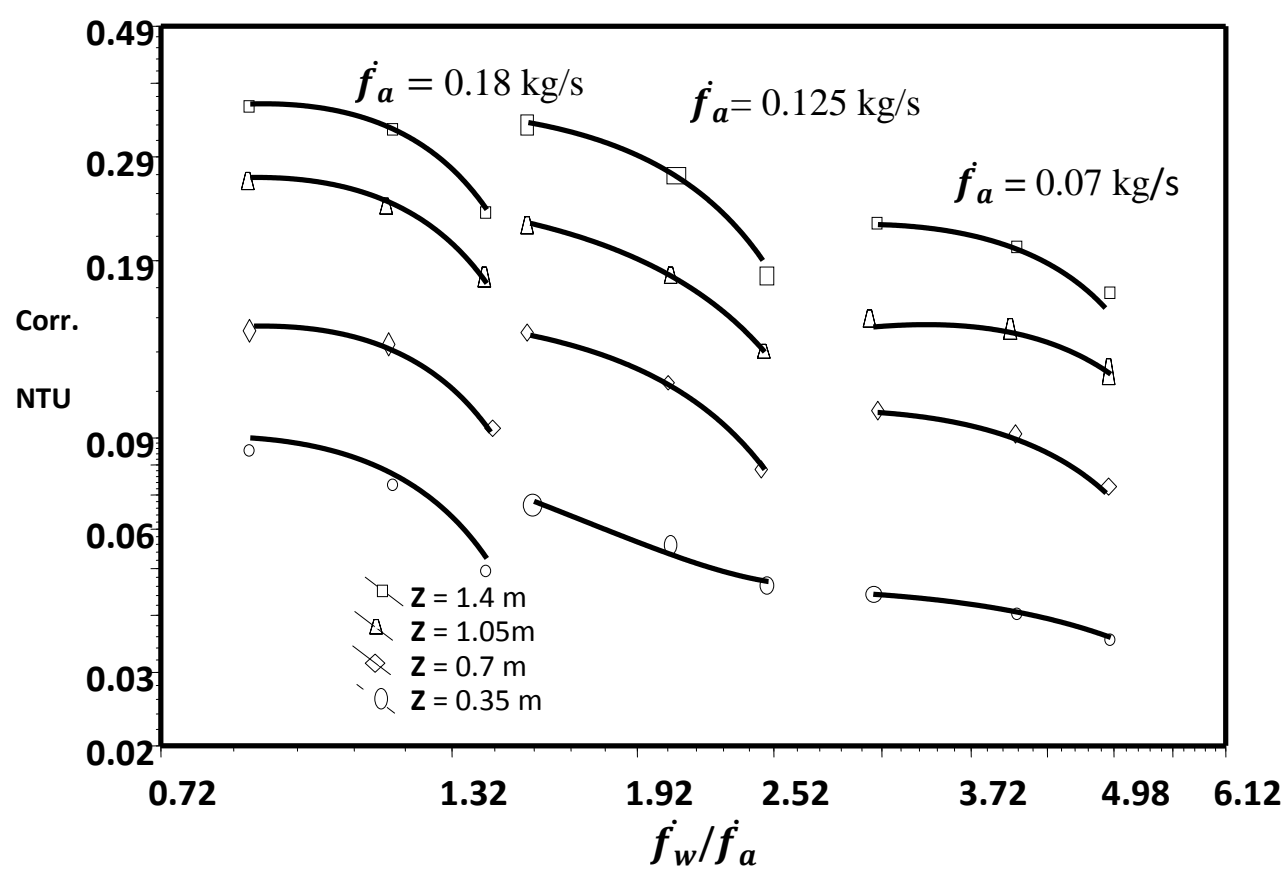

Fig.(23) Corr. NTU vs. $\dot{f_{w}} / \dot{f}_{a}$ for triangular thermoplastic packing, $\mathrm{T}_{\mathrm{wt}}=45 \mathrm{C}^{\mathrm{o}}$

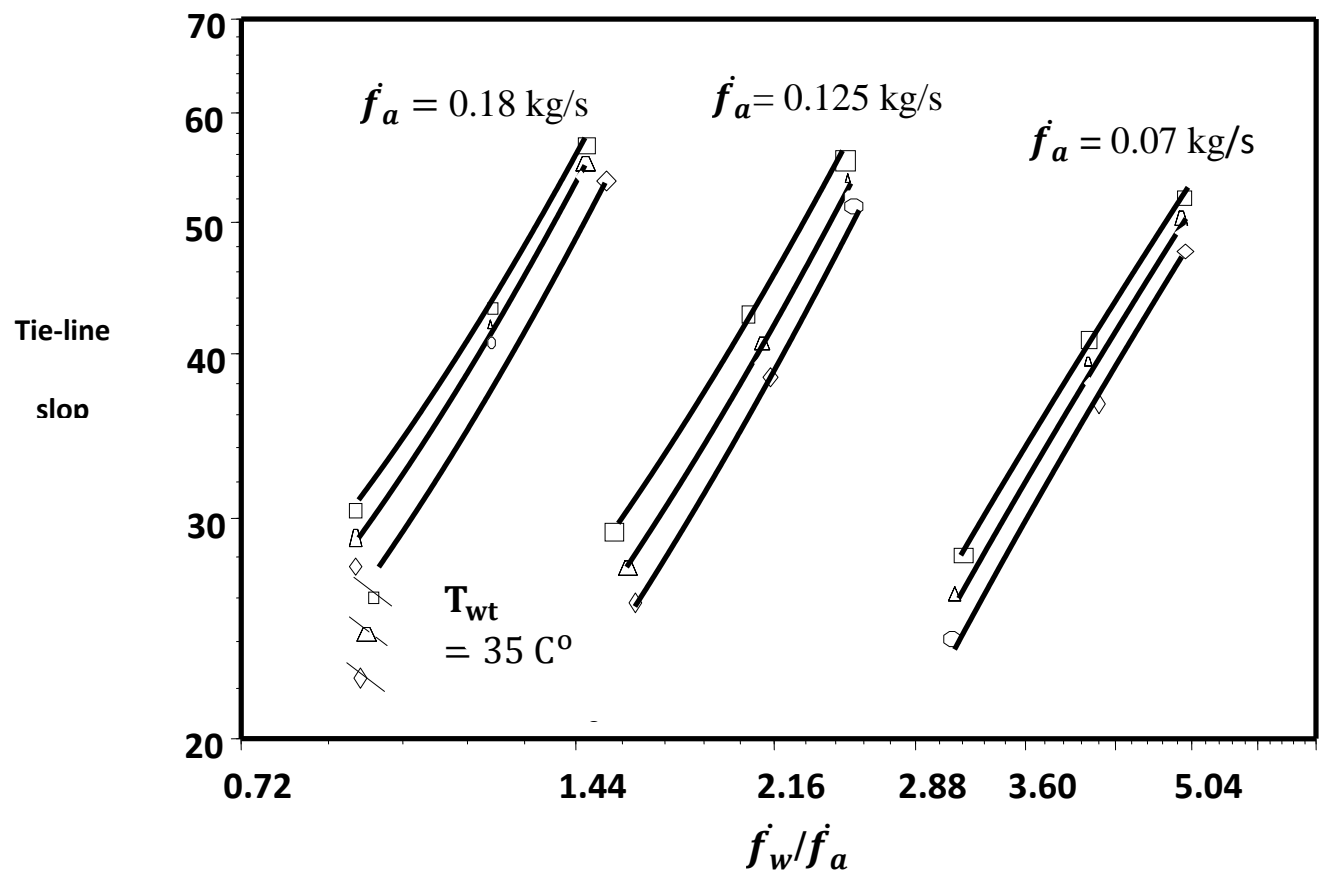

Fig.(24) Tie-line Slope vs. $\dot{f_{w}} / \dot{f_{a}}$ for triangular thermoplastic packing, and $\mathrm{Z}=0.35 \mathrm{~m}$ 


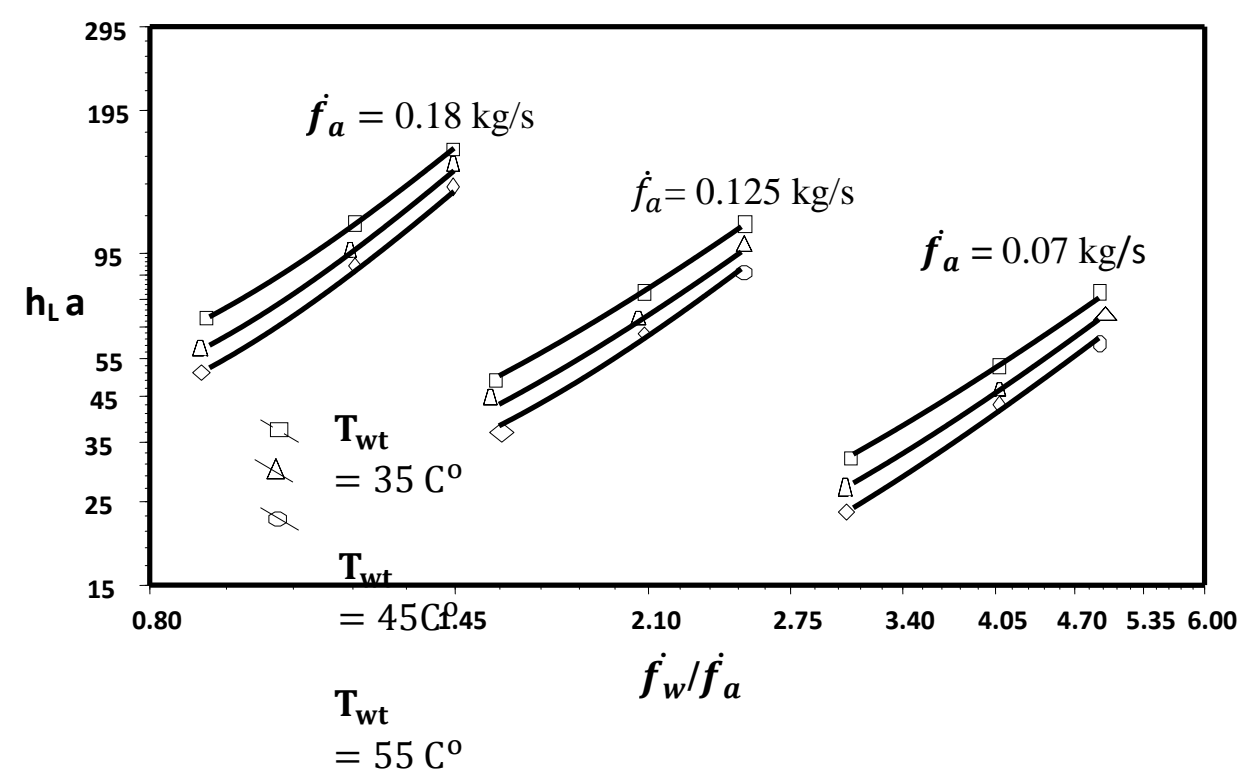

Fig.(25) Liquid side heat transfer coefficient vs. $\dot{f}_{w} / \dot{f}_{a}$ for triangular thermoplastic packing, and $\mathrm{Z}=0.35 \mathrm{~m}$ 